\title{
molecules
}

ISSN 1420-3049

www.mdpi.com/journal/molecules

Article

\section{Multidimensional Transition Metal Complexes Based on 3-Amino-1H-1,2,4-triazole-5-carboxylic Acid: From Discrete Mononuclear Complexes to Layered Materials}

\author{
Bing Liu ${ }^{1,2, \dagger}$, José A. Fernandes ${ }^{1, \dagger}$, João P. C. Tomé ${ }^{3,4}$, Filipe A. Almeida Paz ${ }^{1, *}$ \\ and Luís Cunha-Silva ${ }^{2, *}$
}

1 Department of Chemistry, CICECO-Aveiro Institute of Materials, University of Aveiro, Campus Universitário de Santiago, 3810-193 Aveiro, Portugal;

E-Mails: bliu_1203@163.com (B.L.); jafernandes@ua.pt (J.A.F.)

2 REQUIMTE/LAQV \& Department of Chemistry and Biochemistry, Faculty of Sciences, University of Porto, 4169-007 Porto, Portugal

3 Department of Chemistry, University of Aveiro, QOPNA, Campus Universitário de Santiago, 3810-193 Aveiro, Portugal; E-Mail: jtome@ua.pt

4 Department of Organic and Macromolecular Chemistry, Ghent University, B-9000 Ghent, Belgium

$\dagger$ These authors contributed equally to this work.

* Authors to whom correspondence should be addressed; E-Mails: filipe.paz@ua.pt (F.A.A.P.); 1.cunha.silva@fc.up.pt (L.C.-S.); Tel.: +351-234-370-200 (ext. 23553) (F.A.A.P.); +351-220-402-576 (L.C.-S.); Fax: +351-234-370-084 (F.A.A.P.); +351-220-402-659 (L.C.-S.).

Academic Editor: Dong-Sheng Li

Received: 1 June 2015 / Accepted: 25 June 2015 / Published: 7 July 2015

\begin{abstract}
The synthesis and structural characterization of five transition metal complexes with different dimensionality and incorporating residues of 3-amino-1H-1,2,4-triazole-5carboxylic acid ( $\mathrm{H}_{2}$ atrc) is reported: $\left[\mathrm{Zn}(\mathrm{Hatrc})_{2}\left(\mathrm{H}_{2} \mathrm{O}\right)\right](\mathbf{1})$, [ $\left.\mathrm{Mn}(\mathrm{Hatrc})_{2}\left(\mathrm{H}_{2} \mathrm{O}\right)_{2}\right] \cdot 2 \mathrm{H}_{2} \mathrm{O}(\mathbf{2})$, $\left[\mathrm{Fe}_{2}(\mathrm{Hatrc})_{4}(\mathrm{OH})_{2}\right] \cdot 6 \mathrm{H}_{2} \mathrm{O}(3),\left[\mathrm{Cd}(\mathrm{Hatrc})_{2}\left(\mathrm{H}_{2} \mathrm{O}\right)\right]_{n}(4)$, and $\left[\mathrm{Mn}(\operatorname{atrc})\left(\mathrm{H}_{2} \mathrm{O}\right)\right]_{n} \cdot n \mathrm{H}_{2} \mathrm{O}(\mathbf{5})$. These materials could be prepared from solution (1-3), diffusion (4), or hydrothermal reactions (5) with various anions and L:M ratios. Structural details were revealed by single crystal X-ray diffraction. The discrete units composing compounds $\mathbf{1}-\mathbf{3}$, the polymeric $1 \mathrm{D}$ chain of $\mathbf{4}$ and the 2D layer of 5 are further extended into 3D supramolecular architectures through the formation of hydrogen bonds.
\end{abstract}


Keywords: 1,2,4-triazole; crystal structures; supramolecular organization

\section{Introduction}

The rational strategy to design new coordination complexes, especially Metal-Organic Frameworks (MOFs) or coordination networks, by self-assembly has received remarkable interest due to their fascinating structural features and potential to be applied as novel functional materials [1-7]. The final assembly can be influenced by numerous factors, such as geometric requirements of metal centers, shape and nature of the ligands, reaction routes, solvents, templates, $\mathrm{pH}$ of the reactive medium and counterions [8-12]. At the moment, immense research activity is focused on integrating the advantages of metal centers and organic spacers in a complementary way. The inorganic component imparts magnetism, mechanical strength and thermal stability, while the organic part offers a way to improved luminescence, structural diversifications, and processability [13-16]. The effort exerted in this field promotes the understanding of the structure-property relationship, being attributed to the purposeful design and controlled synthesis of the aimed complexes [17-21].

One fruitful selection of the organic building units relies on five-membered N-heterocycles, such as pyrazole, imidazole, triazole, tetrazole, which are good representatives for small and simple organic bridging ligands. 1,2,4-Triazole residues, presenting a hybrid of pyrazole and imidazole, represent a class of ligands that can combine different substituent groups, thus constituting a good building block for the preparation of metal complexes and materials with structural, optical and magnetic properties [22-31]. Herein, 3-amino-1H-1,2,4-triazole-5-carboxylic acid ( $\mathrm{H}_{2}$ atrc) [32], comprising a triazole ring with three $\mathrm{N}$-donors and a carboxylic acid group, was chosen as the organic building unit, being expected to lead to the formation of polynuclear compounds and multidimensional frameworks. A meticulous survey in the literature and in Cambridge Structural Database (CSD, Version 5.36 updated November 2014) [33] revealed the existence of only five structures with residues of $\mathrm{H}_{2}$ atrc (this molecule being the sole organic ligand). Two of these known compounds comprise discrete complexes $\left(\left[\mathrm{Cd}(\operatorname{Hatrc})_{2}\left(\mathrm{H}_{2} \mathrm{O}\right)_{2}\right][34]\right.$ and $\left.\left(\mathrm{NH}_{4}\right)_{2}\left[\mathrm{Cd}(\mathrm{Hatrc})_{4}\right][35]\right)$, whereas the other two are isotypical 3D MOFs $\left(\left[\mathrm{M}(\mathrm{Hatrc})_{2}\left(\mathrm{H}_{2} \mathrm{O}\right)\right] \mathrm{n} ; \mathrm{M}^{2+}=\mathrm{Sr}^{2+}\right.$ or $\mathrm{Ba}^{2+}$ ) [36]. The remaining compound is an interesting tubular structure formed by the crystal packing of $\left[\mathrm{Cu}(\operatorname{atrc})\left(\mathrm{H}_{2} \mathrm{O}\right)\right]$ complex units, whose channels have an internal diameter of $c a$. $8.5 \AA$. Clusters of 12 molecules of water of crystallization are included in the channels [37].

The rarity of $(\mathrm{H})$ atrc-M systems is most likely caused by the fact that $\mathrm{H}_{2}$ atrc produces highly insoluble precipitates, even when using mild synthetic conditions. As part of our ongoing research work dealing with the preparation of functional coordination complexes [38-41] and new MOFs [42-47], we have isolated a series of transition metal (TM) complexes with $\mathrm{H}_{2}$ atrc anionic residues. These materials show distinct dimensionalities and were prepared by several methods: $\left[\mathrm{Zn}(\mathrm{Hatrc})_{2}\left(\mathrm{H}_{2} \mathrm{O}\right)\right](\mathbf{1}),\left[\mathrm{Mn}(\mathrm{Hatrc})_{2}\left(\mathrm{H}_{2} \mathrm{O}\right)_{2}\right] \cdot 2 \mathrm{H}_{2} \mathrm{O}$ (2) (mononuclear complexes), $\left[\mathrm{Fe}_{2}(\mathrm{Hatrc})_{4}(\mathrm{OH})_{2}\right] \cdot 6 \mathrm{H}_{2} \mathrm{O}$ (3; dinuclear complex) were isolated by slow evaporation; $\left[\mathrm{Cd}(\mathrm{Hatrc})_{2}\left(\mathrm{H}_{2} \mathrm{O}\right)\right]_{n}\left(4 ; 1 \mathrm{D}\right.$ MOF) was prepared by diffusion method; $\left[\mathrm{Mn}(\operatorname{atrc})\left(\mathrm{H}_{2} \mathrm{O}\right)\right]_{n} \cdot n \mathrm{H}_{2} \mathrm{O}$ (5; 2D MOF) was synthesized using a typical hydrothermal approach. 


\section{Results and Discussion}

\subsection{Synthesis}

All compounds were directly isolated from the solutions or contents of autoclaves mostly as good quality single crystals. The influence of several parameters, such as the type of metal centers, anions, inorganic/organic bases, ligand:metal ratio, volume of water, temperature and stirring in the formation and crystallization of the compounds was investigated. A number of drawbacks in the crystallization process were found:

(i) the use $\mathrm{NaOH}$ or triethylamine $\left(\mathrm{Et}_{3} \mathrm{~N}\right)$ to deprotonate $\mathrm{H}_{2}$ atrc in reactions with transition metal salts (such as $\mathrm{Mn}^{2+}, \mathrm{Fe}^{2+}, \mathrm{Co}^{2+}, \mathrm{Ni}^{2+}, \mathrm{Cu}^{2+}, \mathrm{Zn}^{2+}$ and $\mathrm{Cd}^{2+}$ ) led to poor crystalline powders;

(ii) the use of temperatures above $60^{\circ} \mathrm{C}$ in the reactions with the aforementioned metals also led to the formation of microcrystalline powders;

(iii) with the use of less than ca. $6 \mathrm{~mL}$ of water in the systems mixed crystals of the new materials and the parent $\mathrm{H}_{2}$ atrc ligand were easily produced;

(iv) with $30 \mathrm{~min}$ of stirring, the clear mixed solutions become cloudy and no pure single crystals were produced.

As a result of this study and optimization, the most adequate reaction conditions for each compound were ultimately optimized for a mixture of an aqueous solution of $\mathrm{H}_{2}$ atrc and the metal, without stirring and standing at ambient temperature. The optimized conditions (see Experimental Section for details) were used in the reactions of $\mathrm{H}_{2}$ atrc with several metal salts. The use of distinct $\mathrm{Zn}^{2+}$ salts $\left[\mathrm{ZnCl}_{2}\right.$, $\mathrm{Zn}\left(\mathrm{NO}_{3}\right)_{2} \cdot 6 \mathrm{H}_{2} \mathrm{O}, \mathrm{ZnSO}_{4} \cdot 7 \mathrm{H}_{2} \mathrm{O}$ and $\mathrm{Zn}\left(\mathrm{ClO}_{4}\right) \cdot 6 \mathrm{H}_{2} \mathrm{O}$ ] with $\mathrm{H}_{2}$ atrc at a ratio of 0.1:0.1-0.6 mmol (with a step of $0.1 \mathrm{mmol}$ ) resulted always in the isolation of the same complex 1, indicating that this is a governing product under the fixed conditions. A similar phenomena was observed for the $\mathrm{Mn}^{2+}$ complexes, but the optimized reaction conditions are not suitable for the $\mathrm{Cu}^{2+}, \mathrm{Ni}^{2+}$ and $\mathrm{Co}^{2+}$, whose products appeared as powders $\left[\mathrm{Cu}^{2+}\right.$ and $\mathrm{Ni}^{2+}$ series] or solutions $\left[\mathrm{Co}^{2+}\right.$ series; slow evaporation of the solution did not result in suitable crystals], ultimately indicating that the metal centers play a decisive role in the formation of the final compounds.

While the slow evaporation process allowed the preparation of mononuclear $\left(\left[\mathrm{Zn}(\mathrm{Hatrc})_{2}\left(\mathrm{H}_{2} \mathrm{O}\right)\right](\mathbf{1})\right.$ and $\left.\left[\mathrm{Mn}(\mathrm{Hatrc})_{2}\left(\mathrm{H}_{2} \mathrm{O}\right)_{2}\right] \cdot 2 \mathrm{H}_{2} \mathrm{O}(2)\right)$ and dinuclear $\left(\left[\mathrm{Fe}_{2}(\mathrm{Hatrc})_{4}(\mathrm{OH})_{2}\right] \cdot 6 \mathrm{H}_{2} \mathrm{O}(3)\right)$ complexes, the diffusion process and hydrothermal reaction conducted to the formation of $1 \mathrm{D}\left(\left[\mathrm{Cd}(\mathrm{Hatrc})_{2}\left(\mathrm{H}_{2} \mathrm{O}\right)\right]_{n}(4)\right)$ and $2 \mathrm{D}$ $\left(\left[\mathrm{Mn}(\operatorname{atrc})\left(\mathrm{H}_{2} \mathrm{O}\right)\right]_{n} \cdot n \mathrm{H}_{2} \mathrm{O}(\mathbf{5})\right)$ coordination networks.

\subsection{Mononuclear Complexes}

Complex 1, [ $\left.\mathrm{Zn}(\mathrm{Hatrc})_{2}\left(\mathrm{H}_{2} \mathrm{O}\right)\right]$, crystallizes in the orthorhombic space group $\mathrm{Pbcn}$ with a crystallographic $C_{2}$ rotation axis located along the $\mathrm{Zn} 1-\mathrm{O} 1 \mathrm{~W}$ bond. The metal center coordinates to one water molecule to two symmetry related $\mathrm{Hatrc}^{-}$moieties, having a distorted trigonal bipyramidal coordination geometry whose triangular equatorial plane is formed by $\mathrm{O} 1 \mathrm{~W}, \mathrm{~N} 14$ and $\mathrm{N} 14^{a}$ (symmetry operation: $a=1-x, y$, 1.5-z), while the axial positions are occupied by $\mathrm{O} 12$ and $\mathrm{O}_{1} 2^{a}$ atoms (Figure 1). The metal center is ideally located in the triangular plane with no deviation from the best least-squares plane fitted by the three coordinated atoms. The $\left\{\mathrm{ZnN}_{2} \mathrm{O}_{3}\right\}$ trigonal bipyramid displays $\tau=(\beta-\alpha) / 60=0.6255$, where $\alpha$ 
and $\beta$ are the two largest angles found in the metal coordination center (Please note: $\tau=0$ for an ideal square pyramid, and $\tau=1$ for an ideal trigonal bipyramid) [48]. The Hatrc ${ }^{-}$residue adopts a typical $\mathrm{N}$,O-bidentate chelating mode (Scheme 1, type I) with the $\mathrm{Zn}-\mathrm{O}$ and $\mathrm{Zn}-\mathrm{N}$ found within the expected ranges (Table 1). Considering compounds $\mathbf{1}, 2$ and the isotypical $\left[\mathrm{Cd}(\mathrm{Hatrc})_{2}\left(\mathrm{H}_{2} \mathrm{O}\right)_{2}\right] \cdot 2 \mathrm{H}_{2} \mathrm{O}$ [34], the distances between the metal centers and the atoms in the first coordination sphere follow the tendency of the ionic radius $\mathrm{Zn}^{2+}<\mathrm{Mn}^{2+}<\mathrm{Cd}^{2+}$. Conversely, the $\mathrm{O}-\mathrm{M}-\mathrm{N}$ bite angles subtended by the $\mathrm{Hatrc}^{-}$residue follow, as expected, the opposite tendency (Table 1).

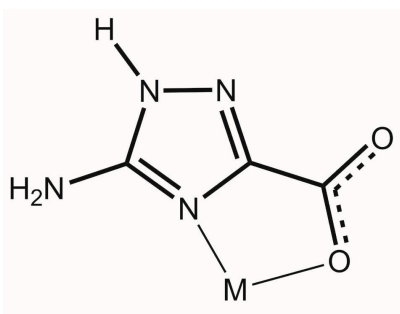

(I)

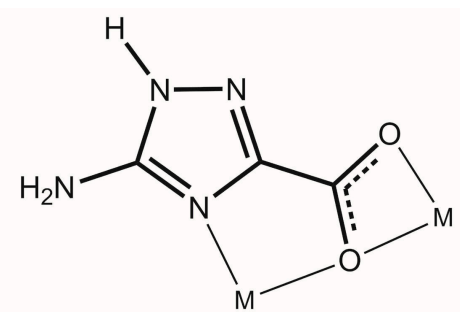

(II)

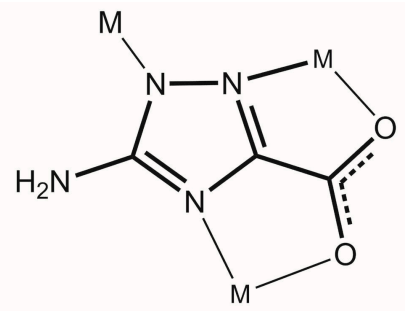

(III)

Scheme 1. Coordination modes of $\mathrm{Hatrc}^{-}$(type I and II) and $\operatorname{atrc}^{2-}$ (type III) anionic residues found in compounds $\mathbf{1}-\mathbf{5}$.

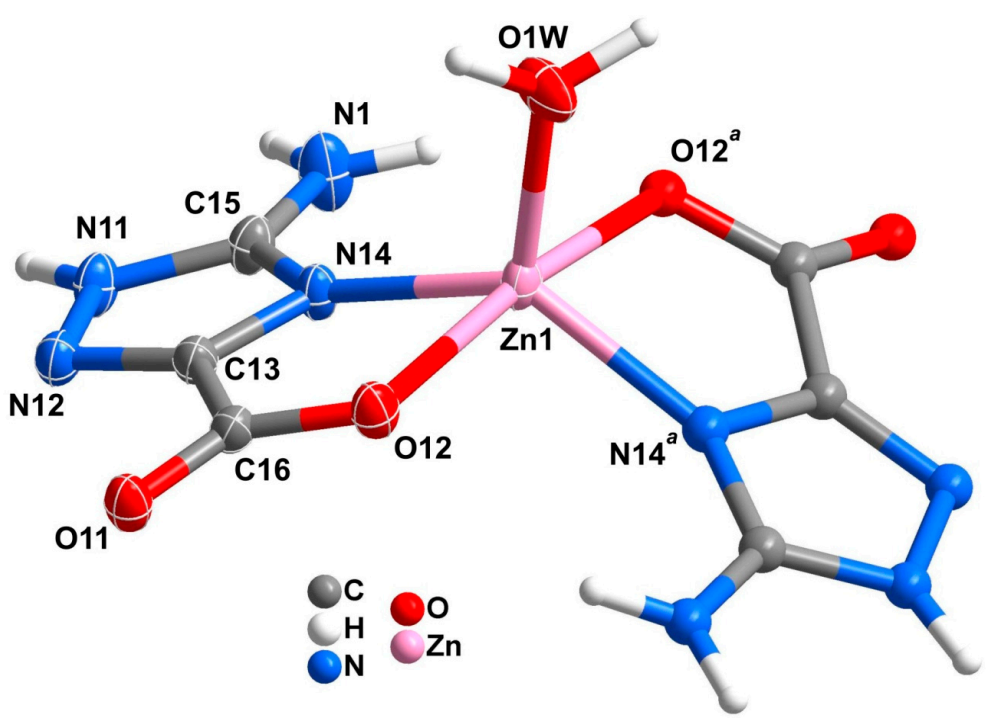

Figure 1. Schematic representation of the mononuclear complex $\left[\mathrm{Zn}(\mathrm{Hatrc})_{2}\left(\mathrm{H}_{2} \mathrm{O}\right)\right]$ present in compound 1, showing the labelling scheme for all non- $\mathrm{H}$ atoms composing the asu and those forming the metal coordination sphere. Non-H atoms of the asu are drawn as thermal ellipsoids at the $30 \%$ probability level and the remaining atoms as spheres with arbitrary radius. For selected bond lengths and angles see Table 1. Symmetry transformation: $a=1-x$, $y, 1.5-z$.

Adjacent $\left[\mathrm{Zn}(\mathrm{Hatrc})_{2}\left(\mathrm{H}_{2} \mathrm{O}\right)\right]$ complexes interact via strong hydrogen bonds leading to the formation of a 2D supramolecular structure (layers) extended in the $a b$ plane of the unit cell (Figure 2a). The intermolecular hydrogen bonds involved in the formation of these layers are of the type $\mathrm{O} 1 \mathrm{~W}-\mathrm{H} 1 \mathrm{WA} \cdots \mathrm{O} 11$ and O1W-H1WA $\cdots \mathrm{O} 12$ (yellow dashed lines in Figure 2a; Table 2). Neighboring 
layers pack close along the [001] direction and are interconnected into a 3D supramolecular architecture network via the N11-H11A $\cdots$ O11 interaction (orange dashed lines in Figure 2b; Table 2). Furthermore, the distance between the centroid of triazole ring and N11 is 3.510(3) Á, pointing to the existence of a weak N11-H11A $\cdots \pi$ stacking interaction in the crystal structure (not shown), which also contributes for the stabilization of the 3D supramolecular architecture.

Table 1. Selected bond lengths $(\AA)$ and angles $\left(^{\circ}\right)$ for the metal coordination centers of mononuclear complexes $\left[\mathrm{Zn}(\mathrm{Hatrc})_{2}\left(\mathrm{H}_{2} \mathrm{O}\right)\right](\mathbf{1}),\left[\mathrm{Mn}(\mathrm{Hatrc})_{2}\left(\mathrm{H}_{2} \mathrm{O}\right)_{2}\right] \cdot 2 \mathrm{H}_{2} \mathrm{O}$ (2) and, for comparison, $\left[\mathrm{Cd}(\mathrm{Hatrc})_{2}\left(\mathrm{H}_{2} \mathrm{O}\right)_{2}\right] \cdot 2 \mathrm{H}_{2} \mathrm{O}[34]$.

\begin{tabular}{|c|c|c|c|c|c|}
\hline \multicolumn{2}{|l|}{1} & \multicolumn{2}{|l|}{2} & \multicolumn{2}{|l|}{$\operatorname{Ref}[34]$} \\
\hline Zn1-O1W & $1.975(5)$ & Mn1-O1W & $2.206(2)$ & $\mathrm{Cd} 1-\mathrm{O} 3$ & $2.384(2)$ \\
\hline $\mathrm{Zn} 1-\mathrm{N} 14$ & $1.981(3)$ & Mn1-N14 & $2.239(3)$ & $\mathrm{Cd} 1-\mathrm{N} 1$ & $2.255(3)$ \\
\hline $\mathrm{Zn} 1-\mathrm{O} 12$ & $2.171(3)$ & $\mathrm{Mn} 1-\mathrm{O} 1$ & $2.186(2)$ & $\mathrm{Cd} 1-\mathrm{O} 1$ & $2.345(2)$ \\
\hline $\mathrm{N} 14-\mathrm{Zn} 1-\mathrm{O} 12$ & $79.57(12)$ & O1-Mn1-N14 & $76.23(8)$ & $\mathrm{O} 1-\mathrm{Cd} 1-\mathrm{N} 1$ & $73.14(5)$ \\
\hline $\mathrm{O} 12-\mathrm{Zn} 1-\mathrm{O} 12^{a}$ & $168.94(17)$ & $\mathrm{O} 1-\mathrm{Mn} 1-\mathrm{O} 1^{b}$ & 180.0 & & \\
\hline $\mathrm{O} 1 \mathrm{~W}-\mathrm{Zn} 1-\mathrm{O} 12$ & $95.53(9)$ & O1-Mn1-O1W & $87.38(8)$ & & \\
\hline $\mathrm{N} 14-\mathrm{Zn} 1-\mathrm{N} 14^{a}$ & $131.5(2)$ & $\mathrm{N} 14-\mathrm{Mn} 1-\mathrm{N} 14^{b}$ & 180.0 & & \\
\hline $\mathrm{O} 1 \mathrm{~W}-\mathrm{Zn} 1-\mathrm{N} 14$ & $114.25(11)$ & O1W-Mn1-N14 & $90.44(8)$ & & \\
\hline & & $\mathrm{O} 1-\mathrm{Mn} 1-\mathrm{N} 14^{b}$ & $103.77(8)$ & & \\
\hline & & $\mathrm{O} 1-\mathrm{Mn} 1-\mathrm{O} 1 \mathrm{~W}^{b}$ & $92.62(8)$ & & \\
\hline & & $O 1 W-M n 1-N 14^{b}$ & $89.56(9)$ & & \\
\hline & & $\mathrm{O} 1 \mathrm{~W}-\mathrm{Mn} 1-\mathrm{O} 1 \mathrm{~W}^{b}$ & 180.0 & & \\
\hline
\end{tabular}

Symmetry transformations used to generate equivalent atoms: (a) $1-x, y, 1.5-z ;$ (b) $1-x, 1-y, 1-z$.

Table 2. Hydrogen-bonding geometrical details for the interactions present in the crystal structures of $\left[\mathrm{Zn}(\mathrm{Hatrc})_{2}\left(\mathrm{H}_{2} \mathrm{O}\right)\right](\mathbf{1})$ and $\left[\mathrm{Mn}(\operatorname{Hatrc})_{2}\left(\mathrm{H}_{2} \mathrm{O}\right)_{2}\right] \cdot 2 \mathrm{H}_{2} \mathrm{O}(\mathbf{2})$.

\begin{tabular}{|c|c|c|c|}
\hline & D-H $\cdots A$ & $\mathbf{D} \cdots \mathbf{A} / \AA$ & $<$ DHA $^{\circ}$ \\
\hline \multirow{6}{*}{1} & $\mathrm{~N} 11-\mathrm{H} 11 \mathrm{~A} \cdots \mathrm{O} 11^{c}$ & $2.749(4)$ & 171 \\
\hline & $\mathrm{N} 1-\mathrm{H} 1 \mathrm{~A} \cdots \mathrm{O} 12^{a}$ & $3.191(5)$ & 141 \\
\hline & $\mathrm{N} 1-\mathrm{H} 1 \mathrm{~A} \cdots \mathrm{O} 1 \mathrm{~W}^{d}$ & $3.322(4)$ & 144 \\
\hline & $\mathrm{N} 1-\mathrm{H} 1 \mathrm{~A} \cdots \mathrm{N} 12^{c}$ & $2.964(5)$ & 167 \\
\hline & $\mathrm{O} 1 \mathrm{~W}-\mathrm{H} 1 \mathrm{WA} \cdots \mathrm{O} 11^{e}$ & $2.781(3)$ & 158 \\
\hline & $\mathrm{O} 1 \mathrm{~W}-\mathrm{H} 1 \mathrm{WA} \cdots \mathrm{O} 12^{e}$ & $3.031(3)$ & 131 \\
\hline \multirow{9}{*}{2} & $\mathrm{~N} 11-\mathrm{H} 11 \mathrm{~A} \cdots \mathrm{O}^{2} \mathrm{~W}^{f}$ & $2.820(3)$ & 142 \\
\hline & $\mathrm{N} 12-\mathrm{H} 12 \mathrm{~A}^{\cdots} \mathrm{O} 2 \mathrm{~W}^{g}$ & $2.957(5)$ & 116 \\
\hline & $\mathrm{N} 1-\mathrm{H} 1 \mathrm{~A} \cdots \mathrm{O} 1 \mathrm{~W}^{h}$ & $2.957(4)$ & 173 \\
\hline & $\mathrm{N} 1-\mathrm{H} 1 \mathrm{~B} \cdots \mathrm{O} 2 \mathrm{~W}^{f}$ & $3.115(4)$ & 142 \\
\hline & $\mathrm{N} 1-\mathrm{H} 1 \mathrm{~B} \cdots \mathrm{O} 2 \mathrm{~W}^{h}$ & $3.141(4)$ & 128 \\
\hline & $\mathrm{O} 1 \mathrm{~W}-\mathrm{H} 1 \mathrm{WA} \cdots \mathrm{O} 1^{i}$ & $2.689(3)$ & 160 \\
\hline & $\mathrm{O} 1 \mathrm{~W}-\mathrm{H} 1 \mathrm{WB} \cdots \mathrm{O} 2^{j}$ & $2.639(3)$ & 162 \\
\hline & $\mathrm{O} 2 \mathrm{~W}-\mathrm{H} 2 \mathrm{WB} \cdots \mathrm{O} 2^{j}$ & $2.757(3)$ & 175 \\
\hline & $\mathrm{O} 2 \mathrm{~W}-\mathrm{H} 2 \mathrm{WA} \cdots \mathrm{N} 12^{k}$ & $2.959(3)$ & 152 \\
\hline
\end{tabular}

Symmetry transformations: (a) $1-x, y, 1.5-z ;(c)-0.5+x, 0.5-y, 2-z ;(d)-0.5+x,-0.5+y, 1.5-z ;(e)-0.5+x$, $0.5+y, 1.5-z ;(f)-x, 1-y,-z ;(g) x,-1+y, z ;(h)-1+x, y, z ;(i) 2-x, 1-y, 1-z ;(j) x, 1+y, z ;(k) 1-x, 1-y,-z$. 

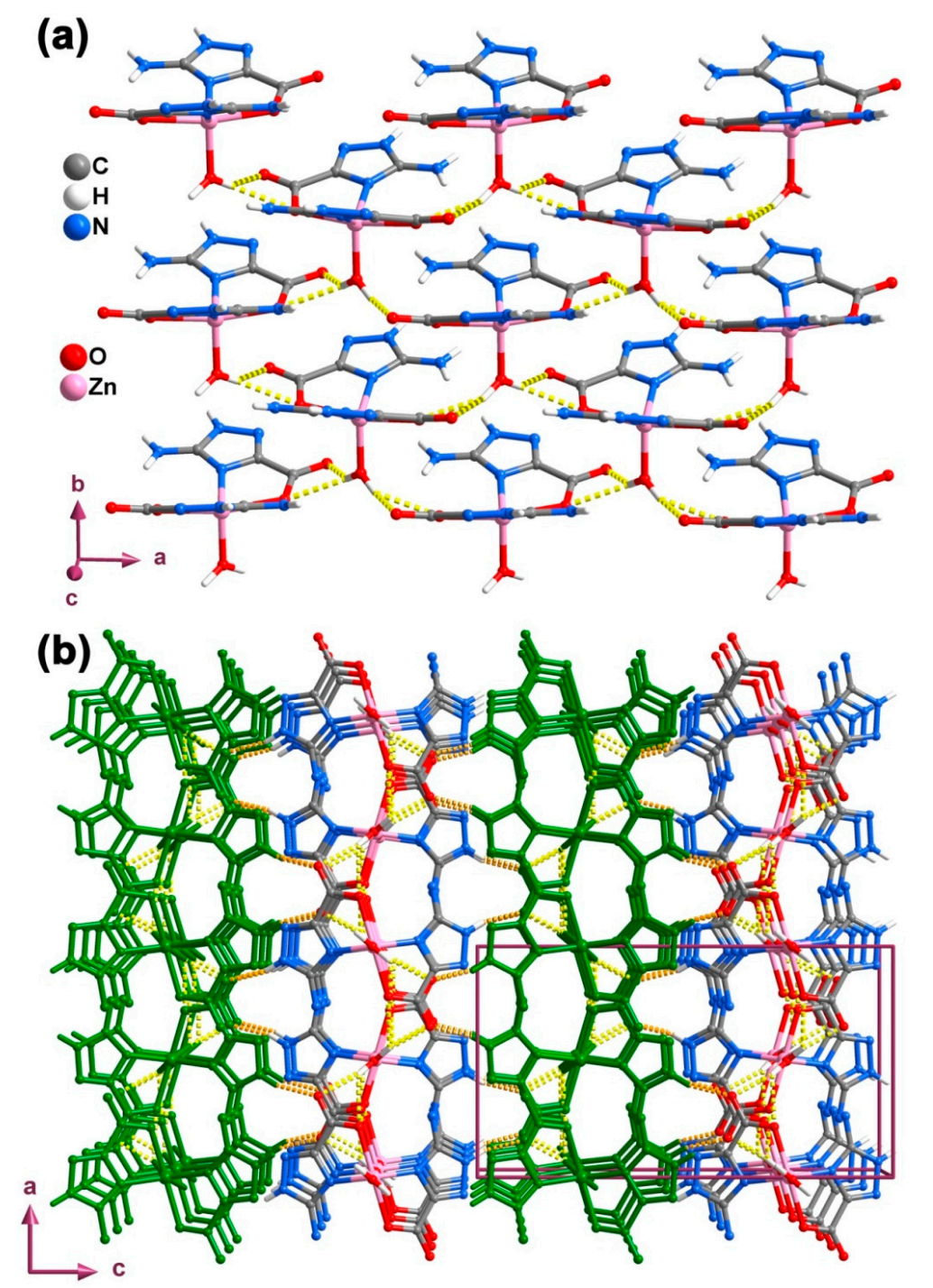

Figure 2. Ball-and-stick representation of (a) the 2D hydrogen-bonded network and (b) 3D hydrogen-bonded supramolecular network (layers with alternating colors) in the crystal structure of compound 1. Hydrogen bonds are represented as yellow (those forming the 2D network) and orange (inter-layer connections) dashed lines. Geometric details on the represented interactions are listed in Table 2.

Compound 2, $\left[\mathrm{Mn}(\mathrm{Hatrc})_{2}\left(\mathrm{H}_{2} \mathrm{O}\right)_{2}\right] \cdot 2 \mathrm{H}_{2} \mathrm{O}$ features a mononuclear complex (Figure 3 ) with the asu being composed of one metal center (Mn1), one $\mathrm{Hatrc}^{-}$anionic ligand and one coordinated water molecule. An additional uncoordinated water molecule of crystallization is, however, present. The metal center has a distorted octahedron geometry, with the equatorial plane formed by O1, N14 and their symmetrical counterparts $\left(\mathrm{O}^{b}\right.$ and $\mathrm{N}^{1} 4^{b}$, symmetry transformation: $\left.b: 1-x, 1-y, 1-z\right)$; $\mathrm{O} 1 \mathrm{~W}$ and $\mathrm{O}_{1} \mathrm{~W}^{b}$ occupy the axial positions (Figure 3 and Table 1). The coordination fashion of the ligand is of type I, as that observed in compound 1. Bond-valence-sum (BVS) calculations gives a value of 2.02 for $\mathrm{Mn} 1$, indicating that $\mathrm{Mn} 1$ has the +2 oxidation state (command Calc Coord in PLATON [49]). This compound is isotypical to the already described compound $\left[\mathrm{Cd}(\mathrm{Hatrc})_{2}\left(\mathrm{H}_{2} \mathrm{O}\right)_{2}\right] \cdot 2 \mathrm{H}_{2} \mathrm{O}[34]$. 


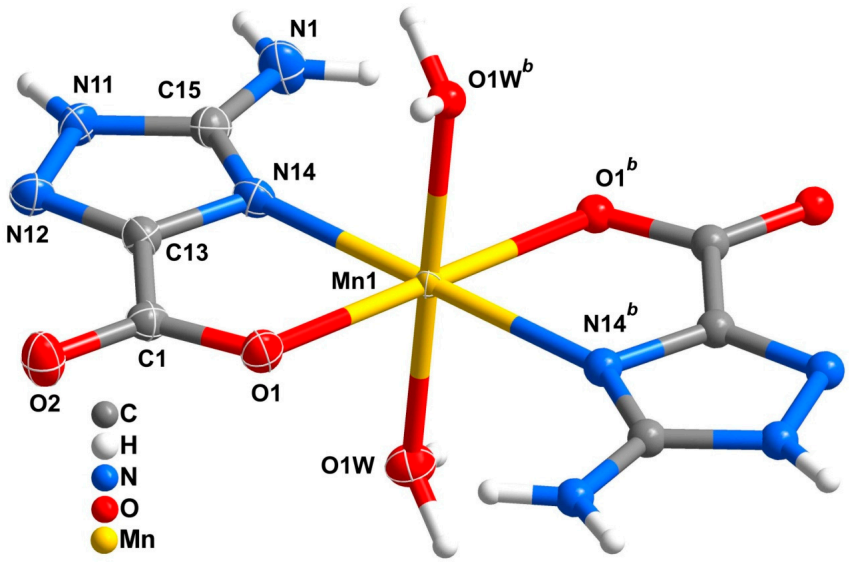

Figure 3. Mononuclear anionic complex $\left[\mathrm{Mn}(\mathrm{Hatrc})_{2}\left(\mathrm{H}_{2} \mathrm{O}\right)_{2}\right]$ found in $\mathbf{2}$ showing the labelling scheme for all non-H atoms composing the asu and the metallic coordination environment. Crystallographically independent non-H atoms are represented as thermal ellipsoids drawn at the $50 \%$ probability level. Symmetry-related atoms are represented as spheres with arbitrary radius. For selected bond lengths and angles see Table 1. Symmetry operation: $b=1-x$, $1-y, 1-z$.

Individual [Mn( $\left.\mathrm{Hatrc})_{2}\left(\mathrm{H}_{2} \mathrm{O}\right)_{2}\right]$ complexes present in compound $\mathbf{2}$ are interconnected through strong hydrogen bonds of type $\mathrm{N}-\mathrm{H} \cdots \mathrm{O} 1 \mathrm{~W}$ involving the coordinated water molecules and adjacent Hatrc ${ }^{-}$ residues into 1D chains running parallel to the $a$-direction of the unit cell (Figure 4a), forming a graph set motif of the type $\mathrm{R}_{2}^{2}(12)$ [50]. Chains further grow into supramolecular layers by way of the lattice water molecules $\mathrm{O} 2 \mathrm{~W}$, which act as bridges between adjacent chains: $\mathrm{O} 2 \mathrm{~W}-\mathrm{H} 2 \mathrm{WB} \cdots \mathrm{O} 2, \mathrm{O} 2 \mathrm{~W}-\mathrm{H} 2 \mathrm{WA} \cdots \mathrm{N} 12$ and N11-H11A $\cdots \mathrm{O} 2 \mathrm{~W}$ (Figure $4 \mathrm{~b}$ and Table 3 ). Layers pack along the $b$-axis of the unit cell mediated by hydrogen bonds, ultimately originating the extended 3D supramolecular structure in 2 (Figure 4c).

(a)

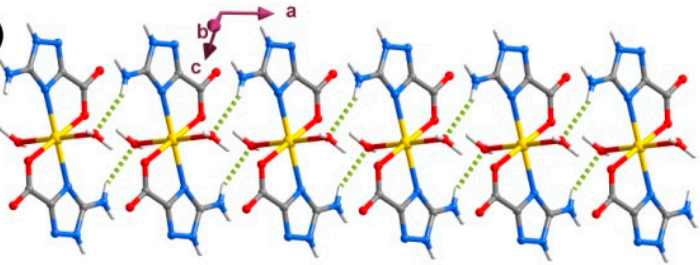

(c)
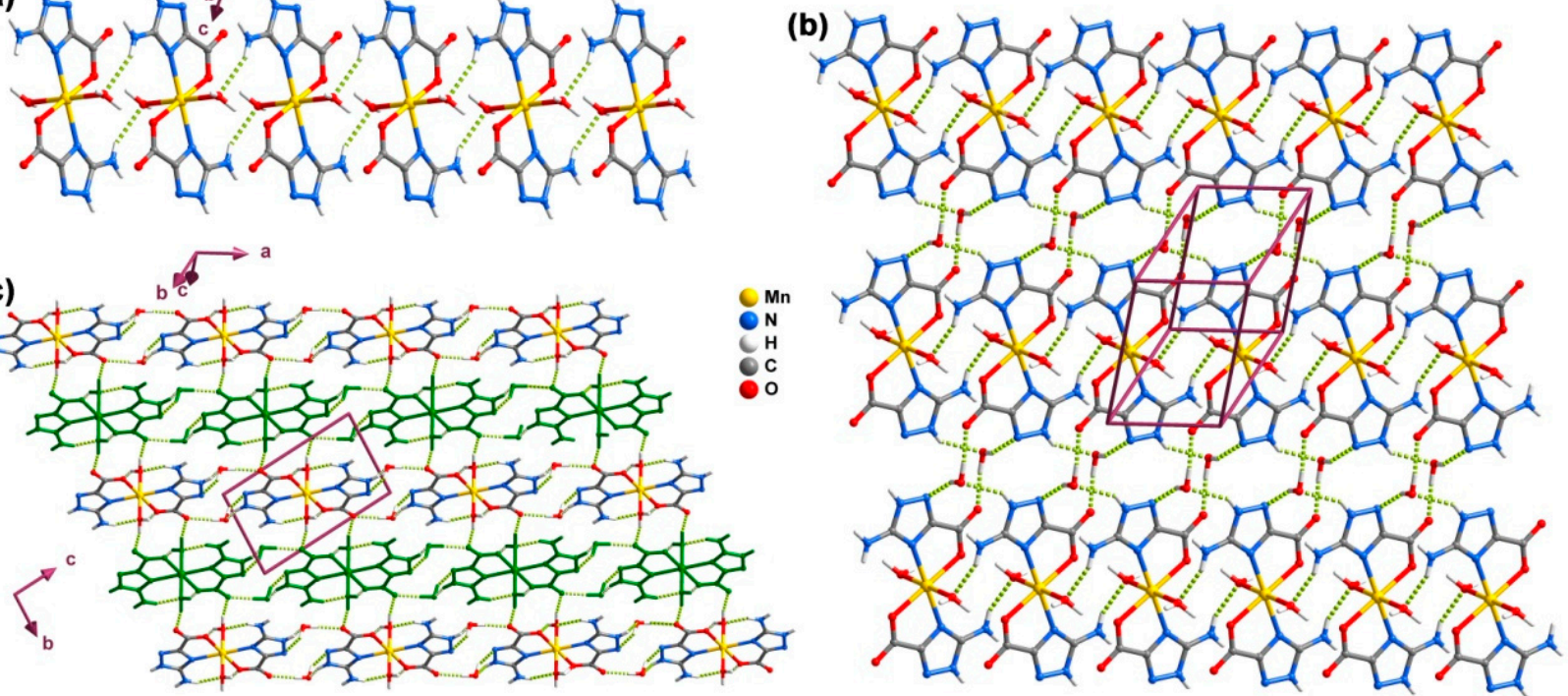

Figure 4. Ball-and-stick representation of (a) the 1D hydrogen-bonded chain; (b) the 2D layer and (c) the 3D supramolecular network (layers alternating between original and green color) present in compound 2. Hydrogen bonds are represented by dashed light-green lines. For details on the represented interactions see Table 2. 
Table 3. Selected bond lengths $(\AA)$ and angles $\left(^{\circ}\right)$ of the binuclear complex $\left[\mathrm{Fe}_{2}(\mathrm{Hatrc})_{4}(\mathrm{OH})_{2}\right]$ present in compound 3, and of the coordination networks $\left[\mathrm{Cd}(\mathrm{Hatrc})_{2}\left(\mathrm{H}_{2} \mathrm{O}\right)\right]_{n}$ (4) and $\left[\mathrm{Mn}(\operatorname{atrc})\left(\mathrm{H}_{2} \mathrm{O}\right)\right]_{n} \cdot n \mathrm{H}_{2} \mathrm{O}(\mathbf{5})$.

\begin{tabular}{|c|c|c|c|c|c|}
\hline 3 & & 4 & & 5 & \\
\hline $\mathrm{Fe} 1-\mathrm{O} 5$ & $1.949(2)$ & $\mathrm{Cd} 1-\mathrm{N} 24$ & $2.239(5)$ & $\mathrm{Mn} 1-\mathrm{N} 12^{n}$ & $2.192(2)$ \\
\hline $\mathrm{Fe} 1-\mathrm{O} 5^{l}$ & $1.979(2)$ & $\mathrm{Cd} 1-\mathrm{N} 14$ & $2.299(5)$ & Mn1-O1W & $2.194(2)$ \\
\hline $\mathrm{Fe} 1-\mathrm{O} 4$ & $2.030(2)$ & $\mathrm{Cd} 1-\mathrm{O} 3$ & $2.344(5)$ & $\mathrm{Mn} 1-\mathrm{O} 1$ & $2.2179(19)$ \\
\hline $\mathrm{Fe} 1-\mathrm{O} 1$ & $2.041(3)$ & $\mathrm{Cd} 1-\mathrm{O} 4^{m}$ & $2.397(4)$ & $\mathrm{Mn} 1-\mathrm{O} 2^{\circ}$ & $2.2531(19)$ \\
\hline $\mathrm{Fe} 1-\mathrm{N} 14$ & $2.096(3)$ & Cd1-O1W & $2.407(5)$ & $\mathrm{Mn} 1-\mathrm{N} 11^{o}$ & $2.255(2)$ \\
\hline \multirow[t]{2}{*}{$\mathrm{Fe} 1-\mathrm{N} 24$} & $2.113(3)$ & $\mathrm{Cd} 1-\mathrm{O} 2$ & $2.434(4)$ & Mn1-N14 & $2.299(2)$ \\
\hline & & $\mathrm{Cd} 1-\mathrm{O} 3^{m}$ & $2.593(4)$ & & \\
\hline $\mathrm{O} 5-\mathrm{Fe} 1-\mathrm{O} 5^{l}$ & $76.37(10)$ & N24-Cd1-N14 & $125.39(19)$ & $\mathrm{N} 12^{n}-\mathrm{Mn} 1-\mathrm{O} 1 \mathrm{~W}$ & $88.23(8)$ \\
\hline O5-Fe1-O4 & $165.65(10)$ & $\mathrm{N} 24-\mathrm{Cd} 1-\mathrm{O} 3$ & $73.44(17)$ & $\mathrm{N} 12^{n}-\mathrm{Mn} 1-\mathrm{O} 1$ & $100.41(8)$ \\
\hline $\mathrm{O} 5-\mathrm{Fe} 1-\mathrm{O} 1$ & $92.88(10)$ & $\mathrm{N} 24-\mathrm{Cd} 1-\mathrm{O} 4^{m}$ & $140.30(17)$ & $\mathrm{N} 12^{n}-\mathrm{Mn} 1-\mathrm{O} 2^{\circ}$ & $168.57(8)$ \\
\hline O5-Fe1-N14 & $97.93(10)$ & $\mathrm{N} 24-\mathrm{Cd} 1-\mathrm{O} 1 \mathrm{~W}$ & $88.15(19)$ & $\mathrm{N} 12^{n}-\mathrm{Mn} 1-\mathrm{N} 11^{o}$ & $97.87(8)$ \\
\hline O5-Fe1-N24 & $97.79(10)$ & $\mathrm{N} 24-\mathrm{Cd} 1-\mathrm{O} 2$ & $87.70(17)$ & $\mathrm{N} 12^{n}-\mathrm{Mn} 1-\mathrm{N} 14$ & $94.18(8)$ \\
\hline $\mathrm{O} 5^{l}-\mathrm{Fe} 1-\mathrm{O} 4$ & $90.56(10)$ & $\mathrm{N} 24-\mathrm{Cd} 1-\mathrm{O} 3^{m}$ & $87.73(17)$ & $\mathrm{O} 1 \mathrm{~W}-\mathrm{Mn} 1-\mathrm{O} 1$ & $94.82(7)$ \\
\hline $\mathrm{O} 5^{l}-\mathrm{Fe} 1-\mathrm{O} 1$ & $164.41(10)$ & $\mathrm{N} 14-\mathrm{Cd} 1-\mathrm{O} 3$ & $88.21(18)$ & $\mathrm{O} 1 \mathrm{~W}-\mathrm{Mn} 1-\mathrm{O} 2^{\circ}$ & $83.68(7)$ \\
\hline $\mathrm{O} 5^{l}-\mathrm{Fe} 1-\mathrm{N} 14$ & $92.25(11)$ & $\mathrm{N} 14-\mathrm{Cd} 1-\mathrm{O} 4^{m}$ & $85.21(17)$ & $\mathrm{O} 1 \mathrm{~W}-\mathrm{Mn} 1-\mathrm{N} 11^{\circ}$ & $98.93(8)$ \\
\hline $\mathrm{O} 5^{l}-\mathrm{Fe} 1-\mathrm{N} 24$ & $95.89(11)$ & N14-Cd1-O1W & $137.85(19)$ & O1W-Mn1-N14 & $170.92(9)$ \\
\hline $\mathrm{O} 4-\mathrm{Fe} 1-\mathrm{O} 1$ & $101.08(10)$ & $\mathrm{N} 14-\mathrm{Cd} 1-\mathrm{O} 2$ & $70.68(17)$ & $\mathrm{O} 1-\mathrm{Mn} 1-\mathrm{O} 2^{\circ}$ & $88.34(7)$ \\
\hline O4-Fe1-N14 & $88.36(10)$ & $\mathrm{N} 14-\mathrm{Cd} 1-\mathrm{O} 3^{m}$ & $127.60(17)$ & $\mathrm{O} 1-\mathrm{Mn} 1-\mathrm{N} 11^{\circ}$ & $157.40(8)$ \\
\hline O4-Fe1-N24 & $77.40(10)$ & $\mathrm{O} 3-\mathrm{Cd} 1-\mathrm{O} 4^{m}$ & $138.78(15)$ & O1-Mn1-N14 & $76.15(8)$ \\
\hline O1-Fe1-N14 & $77.89(11)$ & $\mathrm{O} 3-\mathrm{Cd} 1-\mathrm{O} 1 \mathrm{~W}$ & $77.05(17)$ & $\mathrm{O} 2^{\circ}-\mathrm{Mn} 1-\mathrm{N} 11^{\circ}$ & $75.53(8)$ \\
\hline $\mathrm{O} 1-\mathrm{Fe} 1-\mathrm{N} 24$ & $96.75(11)$ & $\mathrm{O} 3-\mathrm{Cd} 1-\mathrm{O} 2$ & $135.96(16)$ & $\mathrm{O} 2^{\circ}-\mathrm{Mn} 1-\mathrm{N} 14$ & $95.06(8)$ \\
\hline \multirow[t]{7}{*}{ N14-Fe1-N24 } & $163.63(11)$ & $\mathrm{O} 3-\mathrm{Cd} 1-\mathrm{O} 3^{m}$ & $143.57(3)$ & $\mathrm{N} 11^{\circ}-\mathrm{Mn} 1-\mathrm{N} 14$ & $89.42(8)$ \\
\hline & & $\mathrm{O} 4^{m}-\mathrm{Cd} 1-\mathrm{O} 1 \mathrm{~W}$ & $80.97(16)$ & & \\
\hline & & $\mathrm{O} 4^{m}-\mathrm{Cd} 1-\mathrm{O} 2$ & $79.08(15)$ & & \\
\hline & & $\mathrm{O} 4^{m}-\mathrm{Cd} 1-\mathrm{O} 3^{m}$ & $52.60(14)$ & & \\
\hline & & $\mathrm{O} 1 \mathrm{~W}-\mathrm{Cd} 1-\mathrm{O} 2$ & $143.05(16)$ & & \\
\hline & & $\mathrm{O} 1 \mathrm{~W}-\mathrm{Cd} 1-\mathrm{O} 3^{m}$ & $71.32(16)$ & & \\
\hline & & $\mathrm{O} 2-\mathrm{Cd} 1-\mathrm{O} 3^{m}$ & $71.83(15)$ & & \\
\hline
\end{tabular}

Symmetry transformations used to generate equivalent atoms: $(l) x, 0.5-y, 0.5-z ;(m) 1.5-x, 0.5+y, 0.5-z$; (n) $-x, 0.5+y, 0.5-z ;(o) x, 0.5-y, z-0.5$.

\subsection{Binuclear Complex}

Compound 3, [ $\left.\mathrm{Fe}_{2}(\mathrm{Hatrc})_{4}(\mathrm{OH})_{2}\right] \cdot 6 \mathrm{H}_{2} \mathrm{O}$, is composed by a discrete neutral binuclear unit (Figure 5). The asu is composed of one independent $\mathrm{Fe}^{3+}$ center, two anionic Hatrc ligands, one $\mu_{2}$-bridging $\mathrm{OH}^{-}$ anion and three lattice water molecules. Besides the presence of the aforementioned anions, the charge of the metallic center is supported by Bond Valence Sum (BVS) calculations, which produces a value for the ferric atom of $c a$. 3.01, thereby indicating that iron center is indeed in the +3 oxidation state [49]. The six-coordinated Fel center displays a distorted octahedral coordination geometry with the apical positions being occupied by N14 and N24 from two coordinated triazole moieties. The carboxylic oxygen atoms $\mathrm{O} 2$ and $\mathrm{O} 4$ from two distinct carboxylate groups plus $\mathrm{O} 5$ and $\mathrm{O}^{l}$ from two crystallographic 
equivalent hydroxyl moieties shape the equatorial plane of the octahedron (symmetry transformation to generate equivalent atoms: $l=x, 0.5-y, 0.5-z)$. The resulting binuclear $\left[\mathrm{Fe}_{2}(\mathrm{Hatrc})_{4}(\mathrm{OH})_{2}\right]$ complex is thus formed due two $\mu_{2}-\mathrm{OH}^{-}$bridging anions, with the Fe1-O5 distances being 1.954(2) and 1.985(3) $\AA$, well within the expected values for $\mathrm{Fe}-\mathrm{O}$ distances in the $\mathrm{Fe}-\mathrm{OH}-\mathrm{Fe}$ moiety [1.936-2.085 $\AA$, CSD version 5.36, updated in November 2014, 17 observations], and imposing an internuclear Fe ${ }^{\cdots} \mathrm{Fe}^{l}$ separation of 3.087(1) $\AA$ (Figure 5 and Table 3 for geometric details on selected bond lengths and angles). It is noteworthy that the coordination mode of $\mathrm{Hatrc}^{-}$found in $\mathbf{3}$ is identical to that described for compounds $\mathbf{1}$ and 2.

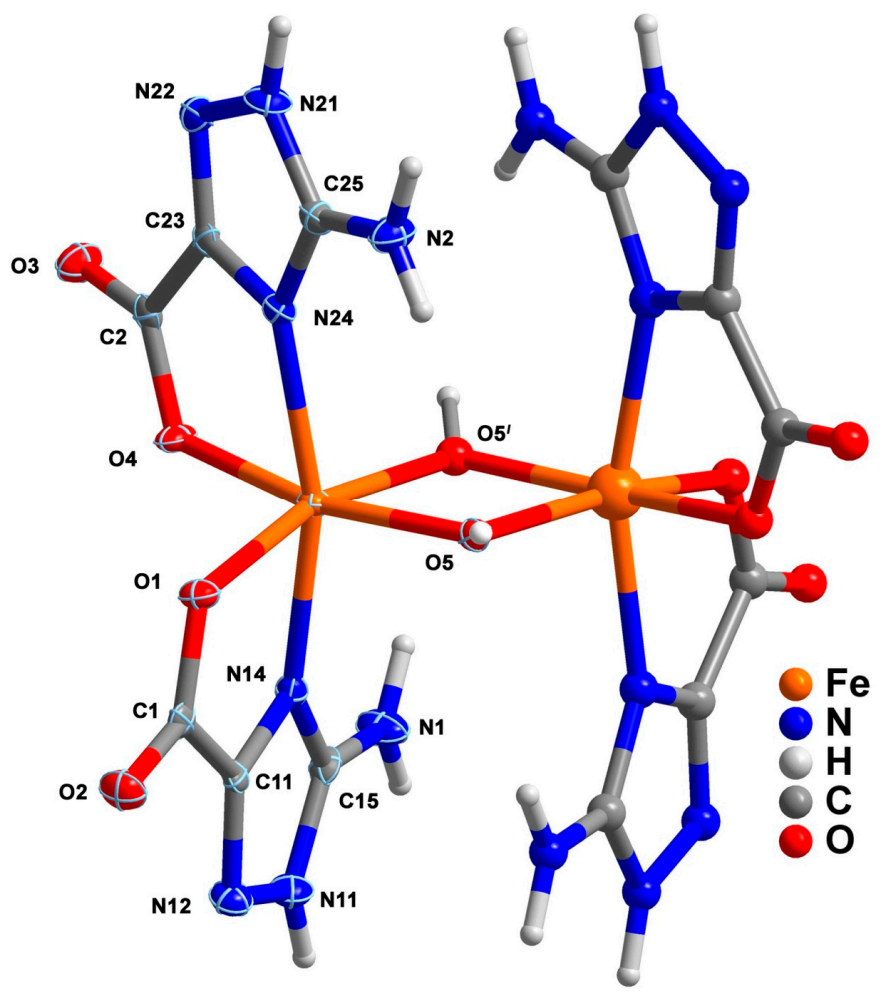

Figure 5. Representation of the binuclear complex $\left[\mathrm{Fe}_{2}(\mathrm{Hatrc})_{4}(\mathrm{OH})_{2}\right]$ present in compound 3, showing the labelling scheme for all non-H atoms composing the asu and the Fe1 coordination environment. Non-H atoms of the asu are represented as thermal ellipsoids (70\% probability level) and the remaining atoms as spheres with arbitrary radii. For selected bond lengths and angles see Table 3. Symmetry operation: $l=x, 0.5-y, 0.5-z$.

Supramolecular interactions are of two main types: those involving solely individual $\mathrm{Fe}^{3+}$ complexes and those that interconnect complexes with lattice water molecules. Neighboring [Fe2( $\left.\mathrm{Hatrc})_{4}(\mathrm{OH})_{2}\right]$ complexes are interconnected through strong hydrogen bonds of the type $\mathrm{N}-\mathrm{H} \cdots \mathrm{O}$ into $1 \mathrm{D}$ supramolecular chains that run parallel to the $c$-direction of the unit cell. 2D supramolecular layers placed in the $b c$ plane of the unit cell are formed by hydrogen bonds of type N1-H1B $\cdots \mathrm{O} 2$ (Figure 6a,b; Table 4 for geometrical details on the hydrogen bonds). Adjacent layers are fused into a 3D supramolecular architecture by ways of several strong $\mathrm{N}-\mathrm{H} \cdots \mathrm{O}, \mathrm{O}-\mathrm{H} \cdots \mathrm{N}$ and $\mathrm{O}-\mathrm{H} \cdots \mathrm{O}$ interactions (Figure $6 \mathrm{c}$ and Table 4). 
Table 4. Geometrical details on the hydrogen bonds present in compound $\left[\mathrm{Fe}_{2}(\mathrm{Hatrc})_{4}(\mathrm{OH})_{2}\right] \cdot 6 \mathrm{H}_{2} \mathrm{O}(3)$.

\begin{tabular}{|c|c|c|c|c|c|}
\hline D-H $\cdots A$ & $\mathbf{D} \cdots \mathbf{A} / \AA$ & $<$ DHA $/{ }^{\circ}$ & D-H $\cdots A$ & $\mathbf{D} \cdots \mathbf{A} / \AA$ & $<$ DHA/ ${ }^{\circ}$ \\
\hline $\mathrm{N} 11-\mathrm{H} 11 \mathrm{~A} \cdots \mathrm{O} 2 \mathrm{~W}$ & $2.746(4)$ & 171 & $\mathrm{O} 1 \mathrm{~W}-\mathrm{H} 1 \mathrm{WA} \cdots \mathrm{O} 3 \mathrm{~W}^{u}$ & $2.847(4)$ & 174 \\
\hline $\mathrm{N} 1-\mathrm{H} 1 \mathrm{~A} \cdots \mathrm{O} 3 \mathrm{~W}^{p}$ & $2.905(4)$ & 151 & $\mathrm{O} 1 \mathrm{~W}-\mathrm{H} 1 \mathrm{WB} \cdots \mathrm{N} 22^{t}$ & $2.914(4)$ & 179 \\
\hline $\mathrm{N} 1-\mathrm{H} 1 \mathrm{~B} \cdots \mathrm{O} 2^{q}$ & $3.023(4)$ & 173 & $\mathrm{O} 2 \mathrm{~W}-\mathrm{H} 2 \mathrm{WA} \cdots \mathrm{O} 1 \mathrm{~W}^{v}$ & $2.678(4)$ & 154 \\
\hline $\mathrm{N} 21-\mathrm{H} 21 \mathrm{~A} \cdots \mathrm{O} 2 \mathrm{~W}^{r}$ & $2.903(4)$ & 135 & $\mathrm{O} 2 \mathrm{~W}-\mathrm{H} 2 \mathrm{WB} \cdots \mathrm{O} 2^{q}$ & $2.842(4)$ & 145 \\
\hline $\mathrm{N} 21-\mathrm{H} 21 \mathrm{~A} \cdots \mathrm{O} 1^{s}$ & $2.866(4)$ & 128 & O3W-H3WA $\cdots$ O 4 & $2.719(3)$ & 166 \\
\hline $\mathrm{N} 2-\mathrm{H} 2 \mathrm{~A} \cdots \mathrm{O} 3{ }^{t}$ & $2.914(4)$ & 163 & $\mathrm{O} 3 \mathrm{~W}-3 \mathrm{WB} \cdots \mathrm{N} 12^{k}$ & $2.830(4)$ & 175 \\
\hline $\mathrm{N} 2-\mathrm{H} 2 \mathrm{~B} \cdots \mathrm{O} 1 \mathrm{~W}$ & $2.872(4)$ & 154 & $\mathrm{O} 5-\mathrm{H} 5 \mathrm{~A} \cdots \mathrm{O} 3^{t}$ & $2.829(3)$ & 159 \\
\hline
\end{tabular}

Symmetry transformations used to generate equivalent atoms: $(k) 1-x, 1-y,-z ;(p) x, 0.5-y,-0.5-z ;(q) 1-x$, $y-0.5, z-0.5 ;(r) 0.5+x y,-z ;(s) 1.5-x, 1-y, z ;(t) x, y, 1+z ;(u) 1.5-x, 1-y, 1+z ;(v) 0.5-x, 0.5-y, 0.5-z$.
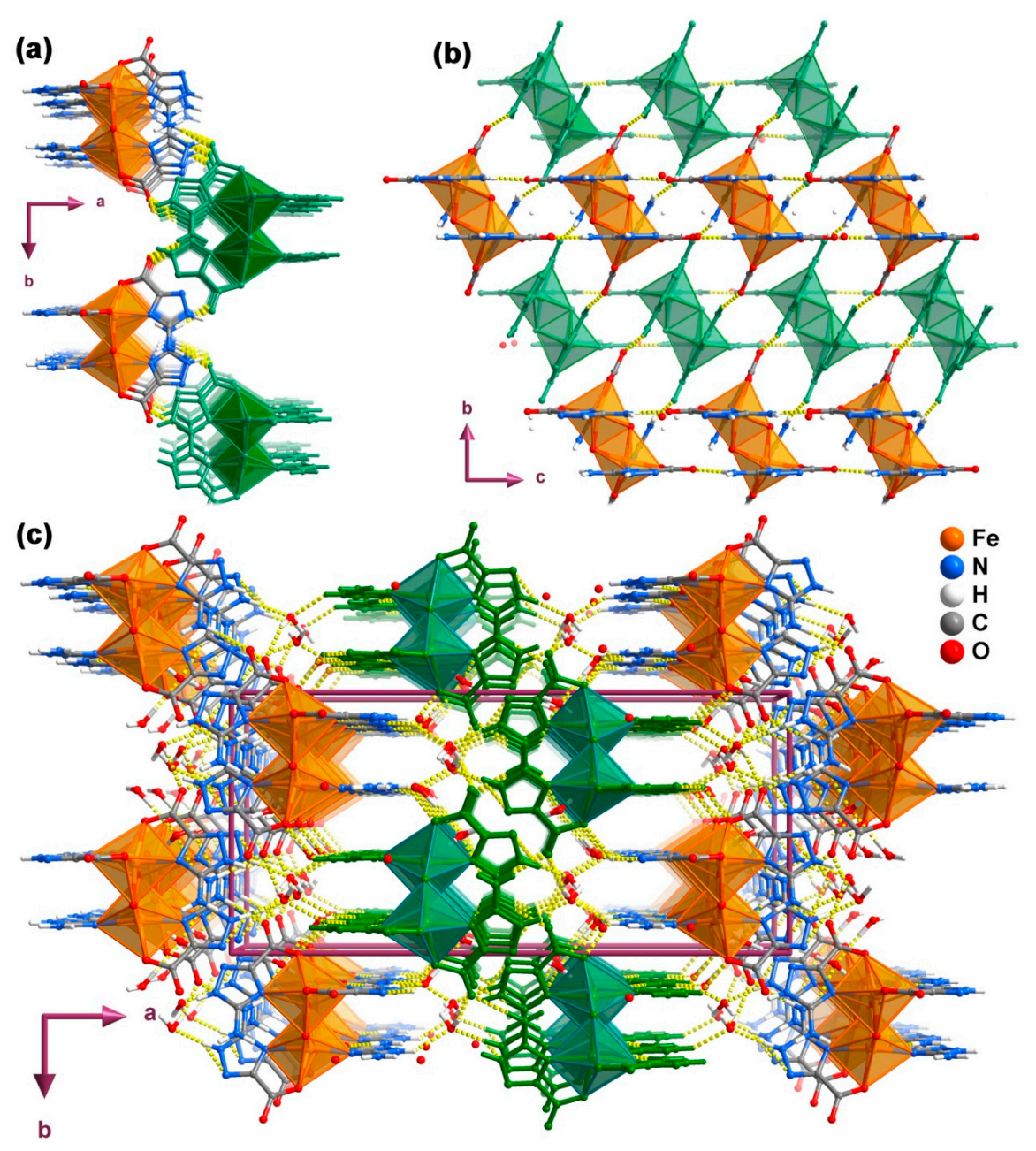

Figure 6. Ball-and-stick representation of the 2D hydrogen-bonded layer present in compound 3 viewed along the (a) [001] and (b) [100] directions of the unit cell (1D supramolecular chains represented in alternate colors); (c) Perspective view of the 3D supramolecular framework (layers alternate between colors) present in the crystal structure of 3. Dashed yellow lines represent the hydrogen bonds. Geometric details on these supramolecular interactions are summarized in Table 4. 


\subsection{One-Dimensional Chain (1D)}

Compound 4, $\left[\mathrm{Cd}(\operatorname{Hatrc})_{2}\left(\mathrm{H}_{2} \mathrm{O}\right)\right]_{n}$, crystallizes in monoclinic space group $P 2_{1} / n$ with one $\mathrm{Cd}^{2+}$ cation, two Hatrc ${ }^{-}$ligands and one coordinated water composing the asu, which features the building unit of a 1D coordination chain (Figure 7). The $\mathrm{Cd} 1$ center coordinates to three $\mathrm{Hatrc}^{-}$anionic ligands and one water molecule (Figure 7a), displaying a coordination geometry which resembles a relatively rare seven-coordinated capped trigonal prism: the atom groups N14, O2, O4 and N24, O3 and O1W build the two opposite triangular facets, and another symmetrical O3 is the capping atom located at the rectangular facet fitted by O2, O4, N24 and O1W (selected bond distances and angles are in given in Table 3). Although seven-coordinated $\mathrm{Cd}^{2+}$ centers are not so numerous as those of four or six-coordinated, a search in the CCDC [33] gives up to 700 related hits. Limiting the search to 1,2,4-triazole residues only, 33 examples of seven-coordinated cadmium(II) are known: three of them are single-capped octahedra [48,51-53] while the remaining ones are pentagonal bipyramids. The two crystallographically distinct Hatrc ${ }^{-}$ligands in compound 4 adopt two different coordination fashions: one is a $\eta^{2}$-type (type $I$ in Scheme 1 ) and the other is $\eta^{4}$-type (type II in Scheme 1). The first coordination mode is the same as those observed in compounds 1-3, chelating to the metal center by one carboxylate $\mathrm{O}$-atom and the 4-positioned $\mathrm{N}$-atom of the triazole ring to form a five-membered ring. The $\eta^{4}$-type $\mathrm{Hatrc}^{-}$ligand adopts both the $\mathrm{N}, \mathrm{O}$-bidente chelating mode described previously, and $O, O$-bidente-chelating mode to bind two adjacent $\mathrm{Cd}^{2+}$ centers: two O-atoms of the carboxylate group chelate to one metal center to form a four-membered ring. As a consequence of the aforementioned linkages of the $\eta^{4}$-Hatrc ${ }^{-}$ligand, the neighboring Cd1 centers are interconnected into wave-like $1 \mathrm{D}[\mathrm{Cd}(\mathrm{Hatrc})]_{n}$ chains running parallel to the $b$-direction of the unit cell and comprising two kinds of five and four-membered rings. The $\eta^{2}$-Hatrc ${ }^{-}$ligands connect $\mathrm{Cd} 1$ centers on both sides of the chain. This, alongside with the coordinated water molecules, ultimately form the 1D coordination polymer (chain) $\left[\mathrm{Cd}(\mathrm{Hatrc})_{2}\left(\mathrm{H}_{2} \mathrm{O}\right)\right]_{n}$ (Figure $\left.7 \mathrm{~b}\right)$.

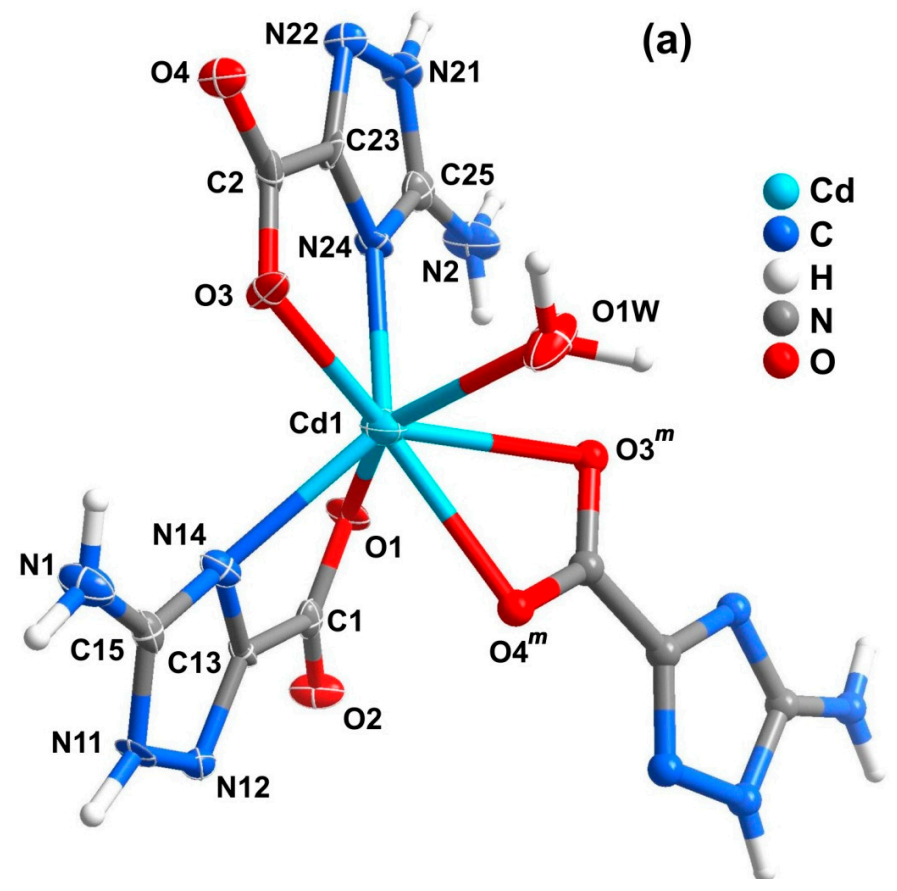

Figure 7. Cont. 
(b)

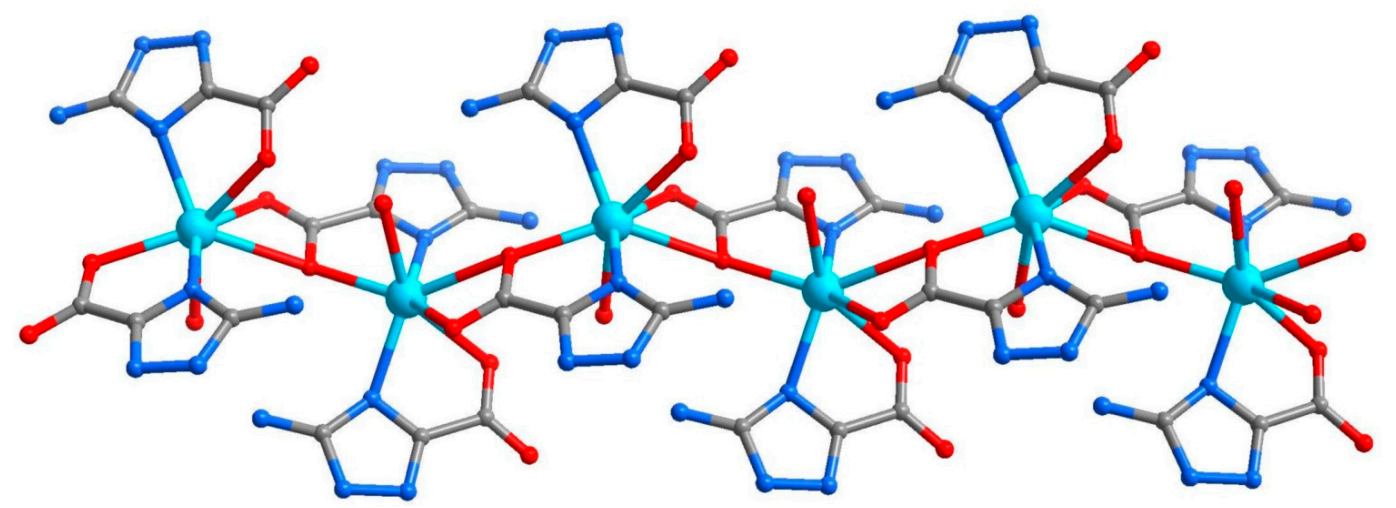

Figure 7. Schematic representation of the (a) $\mathrm{Cd}^{2+}$ coordination environment present in compound $\left[\mathrm{Cd}(\mathrm{Hatrc})_{2}\left(\mathrm{H}_{2} \mathrm{O}\right)\right]_{n}$ (4) showing the labeling scheme for all non-hydrogen atoms composing the asu and the $\mathrm{Cd} 1$ coordination environment. Non- $\mathrm{H}$ atoms of the asu are represented as thermal ellipsoids drawn at the $70 \%$ probability level and the remaining atoms as spheres with arbitrary radii; (b) $1 \mathrm{D}$ coordination chain present in compound 4 . For selected bond lengths (in $\AA$ ) and angles (in degrees) see Table 3. Symmetry operation: $m=1.5-x$, $y+0.5,0.5-z$.

Neighboring chains interact trough cooperative $\mathrm{N}-\mathrm{H} \cdots \mathrm{O}$ hydrogen bonds, in particular interactions of the type N11-H11A $\cdots \mathrm{O} 4, \mathrm{~N} 2-\mathrm{H} 2 \mathrm{~A} \cdots \mathrm{O} 1 \mathrm{~W}$ and $\mathrm{N} 21-\mathrm{H} 21 \mathrm{~A} \cdots \mathrm{O} 1$, leading to the formation of 2D supramolecular layers as depicted in Figure $8 \mathrm{a}$ (see Table 5 for geometrical details on the existent hydrogen bonds). Additionally, these supramolecular layers are interconnected to other adjacent ones via strong $\mathrm{N}-\mathrm{H} \cdots \mathrm{O}$ and $\mathrm{O}-\mathrm{H} \cdots \mathrm{O}$ interactions forming a $3 \mathrm{D}$ supramolecular architecture (Figure $8 \mathrm{~b}$ and Table 5).

Table 5. Geometrical details on the hydrogen bonds present in the supramolecular networks $\left[\mathrm{Cd}(\mathrm{Hatrc})_{2}\left(\mathrm{H}_{2} \mathrm{O}\right)\right]_{n}(\mathbf{4})$ and $\left[\mathrm{Mn}(\operatorname{atrc})\left(\mathrm{H}_{2} \mathrm{O}\right)\right]_{n} \cdot n \mathrm{H}_{2} \mathrm{O}(\mathbf{5})$.

\begin{tabular}{|c|c|c|c|c|c|c|c|}
\hline & D-H $\cdots A$ & $\mathbf{D} \cdots \mathbf{A} / \AA$ & $<$ DHA $^{\circ}$ & & D-H $\cdots A$ & $\mathbf{D} \cdots \mathbf{A} / \AA \AA$ & $<$ DHA $^{\circ}$ \\
\hline \multirow{8}{*}{4} & $\mathrm{~N} 11-\mathrm{H} 11 \mathrm{~A} \cdots \mathrm{O} 4^{w}$ & $2.769(7)$ & 169 & \multirow{8}{*}{5} & $\mathrm{~N} 1-\mathrm{H} 1 \mathrm{~A} \cdots \mathrm{O}^{A}$ & $2.966(3)$ & 156 \\
\hline & $\mathrm{N} 1-\mathrm{H} 1 \mathrm{~A} \cdots \mathrm{O} 1 \mathrm{~W}^{x}$ & $3.200(8)$ & 162 & & $\mathrm{~N} 1-\mathrm{H} 1 \mathrm{~B} \cdots \mathrm{O} 1 \mathrm{~W}^{f}$ & $3.224(3)$ & 151 \\
\hline & $\mathrm{N} 1-\mathrm{H} 1 \mathrm{~B} \cdots \mathrm{N} 22^{w}$ & $3.211(8)$ & 153 & & $\mathrm{O} 1 \mathrm{~W}-\mathrm{H} 1 \mathrm{WA} \cdots \mathrm{O} 2^{b}$ & $2.748(3)$ & 161 \\
\hline & $\mathrm{N} 21-\mathrm{H} 21 \mathrm{~A} \cdots \mathrm{O} 1^{y}$ & $2.684(6)$ & 164 & & $\mathrm{O} 1 \mathrm{~W}-\mathrm{H} 1 \mathrm{WB} \cdots \mathrm{O} 2 \mathrm{~W}^{B}$ & $2.714(3)$ & 152 \\
\hline & $\mathrm{N} 2-\mathrm{H} 2 \mathrm{~A} \cdots \mathrm{O} 1 \mathrm{~W}^{m}$ & $3.064(8)$ & 155 & & $\mathrm{O} 2 \mathrm{~W}-\mathrm{H} 2 \mathrm{WB} \cdots \mathrm{N} 1$ & $2.872(3)$ & 160 \\
\hline & $\mathrm{N} 2-\mathrm{H} 2 \mathrm{~B} \cdots \mathrm{N} 12^{y}$ & $3.037(8)$ & 158 & & $\mathrm{O} 2 \mathrm{~W}-\mathrm{H} 2 \mathrm{WA} \cdots \mathrm{N} 14^{C}$ & $3.186(3)$ & 138 \\
\hline & $\mathrm{O} 1 \mathrm{~W}-\mathrm{H} 1 \mathrm{WB} \cdots \mathrm{O} 1^{z}$ & $2.747(7)$ & 165 & & $\mathrm{O} 2 \mathrm{~W}-\mathrm{H} 2 \mathrm{WA} \cdots \mathrm{N} 12^{D}$ & $3.183(3)$ & 129 \\
\hline & $\mathrm{O} 1 \mathrm{~W}-\mathrm{H} 1 \mathrm{WA} \cdots \mathrm{O} 2^{x}$ & $2.698(7)$ & 158 & & $\mathrm{O} 2 \mathrm{~W}-\mathrm{H} 2 \mathrm{WA} \cdots \mathrm{N} 11^{D}$ & $3.159(3)$ & 121 \\
\hline
\end{tabular}

Symmetry transformations used to generate equivalent atoms: (b) $1-x, 1-y, 1-z ;(f)-x, 1-y,-z ;(m) 1.5-x$, $0.5+y, 0.5-z ;(w) 0.5+x,-0.5-y, z-0.5 ;(x) 1.5-x,-0.5+y, 0.5-z ;(y) 0.5+x, 0.5-y, 0.5+z ;(z) 0.5+x, 0.5-y$, $0.5+z ;(A)-1+x, 0.5-y,-0.5+z ;(B) 1+x, 0.5-y, 0.5-z ;(C) x, 0.5-y, z-0.5 ;(D)-x,-y,-z$. 


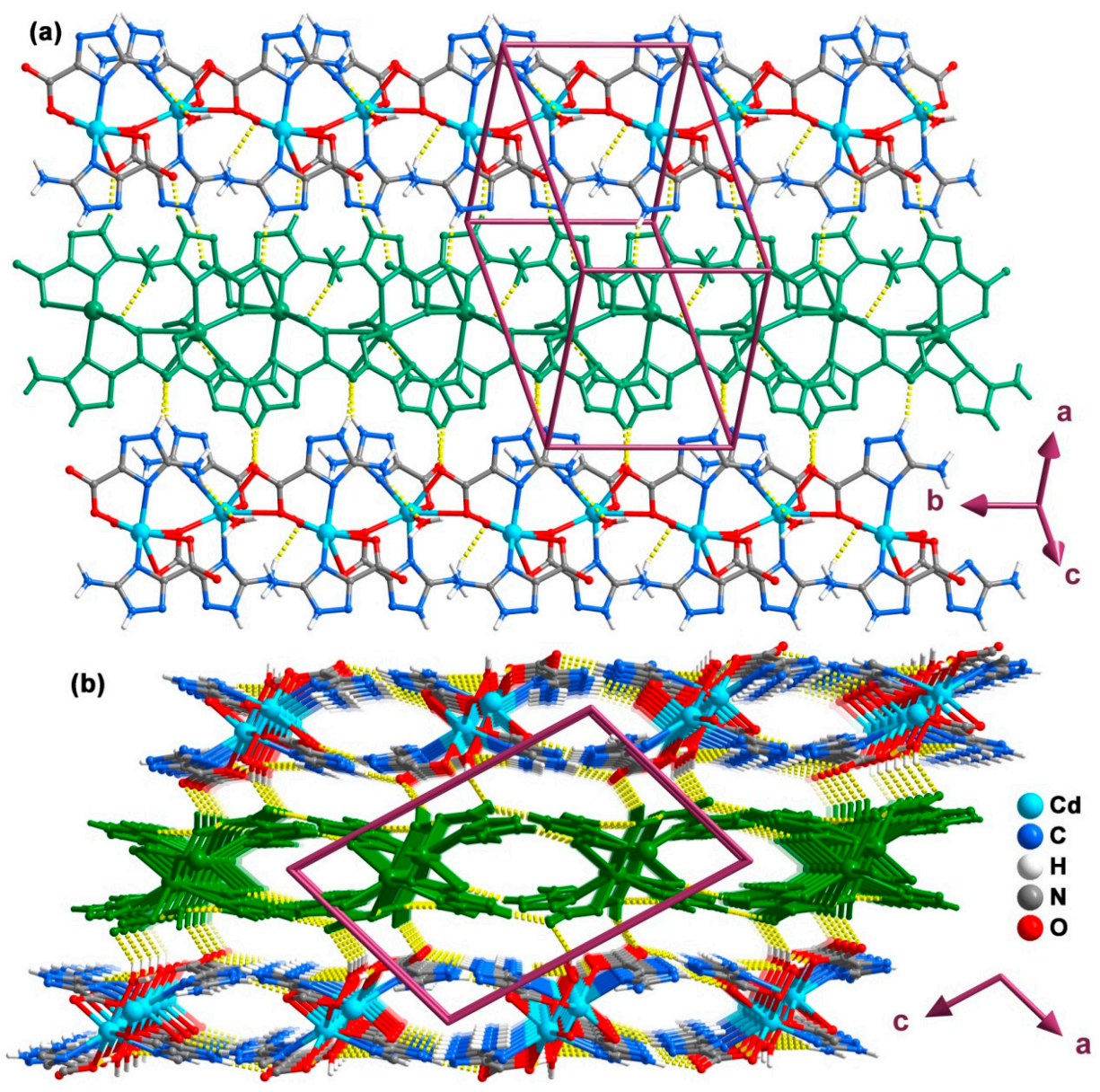

Figure 8. Ball-and-stick representation of the (a) 2D hydrogen-bonded network formed between adjacent 1D coordination chains (represented with alternating colors) and the (b) 3D hydrogen-bonded supramolecular network viewed in perspective along the [010] direction of the unit cell (layers represented with alternating colors) present in compound 4. Hydrogen bonds are represented as dashed yellow lines. Geometric details on these interactions are summarized in Table 5.

\subsection{Coordination Layer $(2 D)$}

The structure of compound $\mathbf{5}$, as unveiled from single-crystal XRD analysis, was formulated as $\left[\mathrm{Mn}(\operatorname{atrc})\left(\mathrm{H}_{2} \mathrm{O}\right)\right] \cdot \mathrm{H}_{2} \mathrm{O}$, featuring a 2D coordination layered structure. The asu comprises one $\mathrm{Mn}^{2+}$ center, one fully deprotonated $\operatorname{atrc}^{2-}$ anionic ligand, one coordinated and one lattice water molecule. The Mn1 metal center is coordinated by three crystallographic equivalent $\operatorname{atrc}^{2-}$ and one water molecule, leading to a six-coordinated coordination environment with a geometry that resembles a distorted octahedron: N14, $\mathrm{N} 12^{n}, \mathrm{O} 2^{\circ}$ and $\mathrm{O} 1 \mathrm{~W}$ atoms form the equatorial plane, and $\mathrm{O} 1$ and $\mathrm{N} 11^{\circ}$ occupy the two axial positions (Figure 9; for details concerning bond lengths and angles see Table 3; symmetry operations: $n=-x$, $0.5+y, 0.5-z$ and $o=x, 0.5-y,-0.5+z$ ). BVS calculations gave a charge of +2.02 for Mn center suggesting that the oxidation state of Mn1 should be +2 , in good agreement with the charge assignment from the crystal structure determination. 


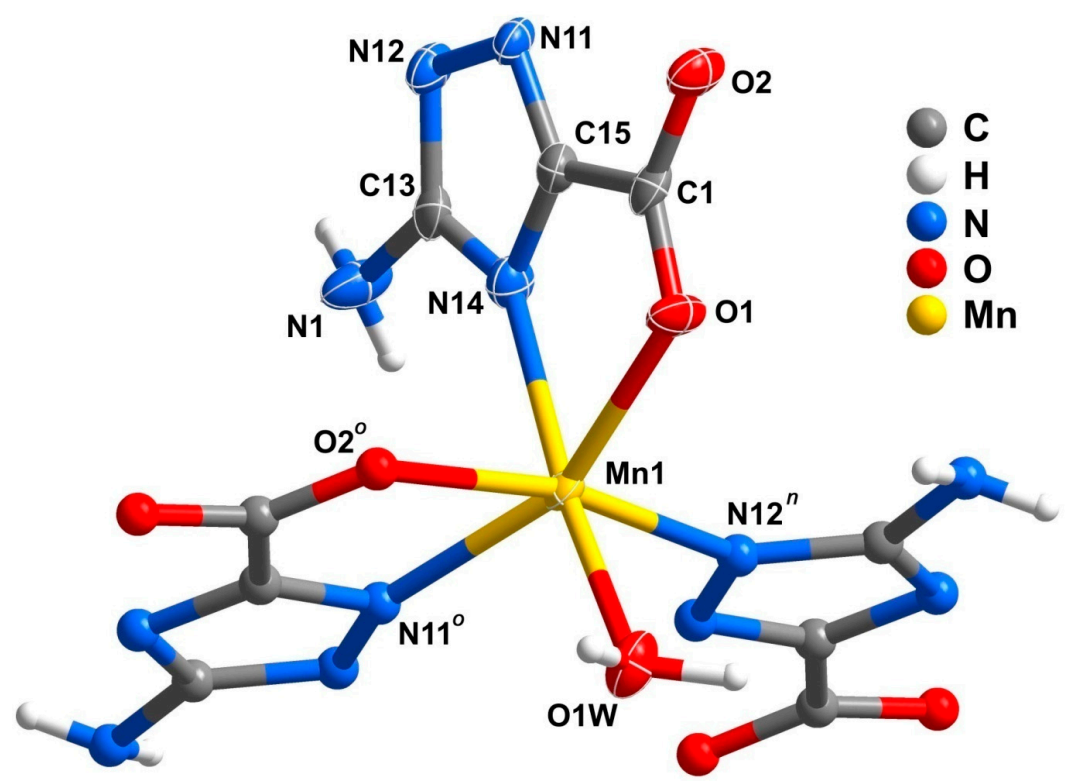

Figure 9. Mixed ellipsoid and ball-and-stick representation of the $\mathrm{Mn}^{2+}$ coordination environment present in compound $\left[\mathrm{Mn}(\operatorname{atrc})\left(\mathrm{H}_{2} \mathrm{O}\right)\right] \cdot \mathrm{H}_{2} \mathrm{O}(\mathbf{5})$, showing the labeling scheme for all non-H atoms composing the asu and the first metal coordination sphere. Non-H atoms of the asu are represented as thermal ellipsoids drawn at the $90 \%$ probability level and the remaining atoms as spheres with arbitrary radius. For selected bond lengths and angles see Table 3. Symmetry operations: $n=-x, 0.5+y, 0.5-z ; o=x, 0.5-y,-0.5+z$.

Each atrc ${ }^{2-}$ residue in 5 connects to three $\mathrm{Mn}^{2+}$ metal centers through two $\mathrm{N}, \mathrm{O}$-bidentate interactions (chelating two metal cations through $\mathrm{N} 11 / \mathrm{O} 2$ and N14/O1) and one monodentate- $N$ mode to bind the fourth $\mathrm{Mn}^{2+}$ by N12 (Scheme 1, type III). As a consequence of these coordination modes, a 2D coordination framework (layer) based on the interconnection of [ $\left.\mathrm{Mn}_{8}(\mathrm{atrc})_{8}\right]$ macro rings is ultimately (Figure 10a). The 2D layers pack along the [100] direction of the unit cell being mediated by numerous strong $\mathrm{O}-\mathrm{H} \cdots \mathrm{O}, \mathrm{O}-\mathrm{H} \cdots \mathrm{N}$ and $\mathrm{N}-\mathrm{H} \cdots \mathrm{O}$ hydrogen-bonding interaction leading to the formation of a $3 \mathrm{D}$ supramolecular architecture (Figure 10b).

The coordination fashions of the organic ligand (Scheme 1) can be related with the structural features and dimensionality of the reported complexes. In mild conditions, $\mathrm{H}_{2}$ atrc tends to firstly deprotonate the hydrogen atom of the carboxylic acid group. The resulting anionic Hatrc ligand chelates one metal center using the 4-positioned $\mathrm{N}$-atom and one $\mathrm{O}$-atom of the carboxylate group to form a rather stable five-membered chelate ring (type I in Scheme 1), as observed in compounds 1-3. The coordination fashion of $\mathrm{Hatrc}^{-}$in compound 4 (type II in Scheme 1) has one more chelating carboxylate group than type I. Usually, a more complex coordination fashion tends to promote more complicated structures. With the use of a higher synthetic temperature and the presence of a strong base $\left(\mathrm{NaN}_{3}\right.$ or $\left.\mathrm{NaOH}\right)$, the hydrogen atom on the 1-positioned $\mathrm{N}$ is liberated, thereby giving rise to a bidentate-chelating- $N, O$ and one monodentate- $N$ coordination donor (type III) contributing to the construction of a higher dimensional network. 


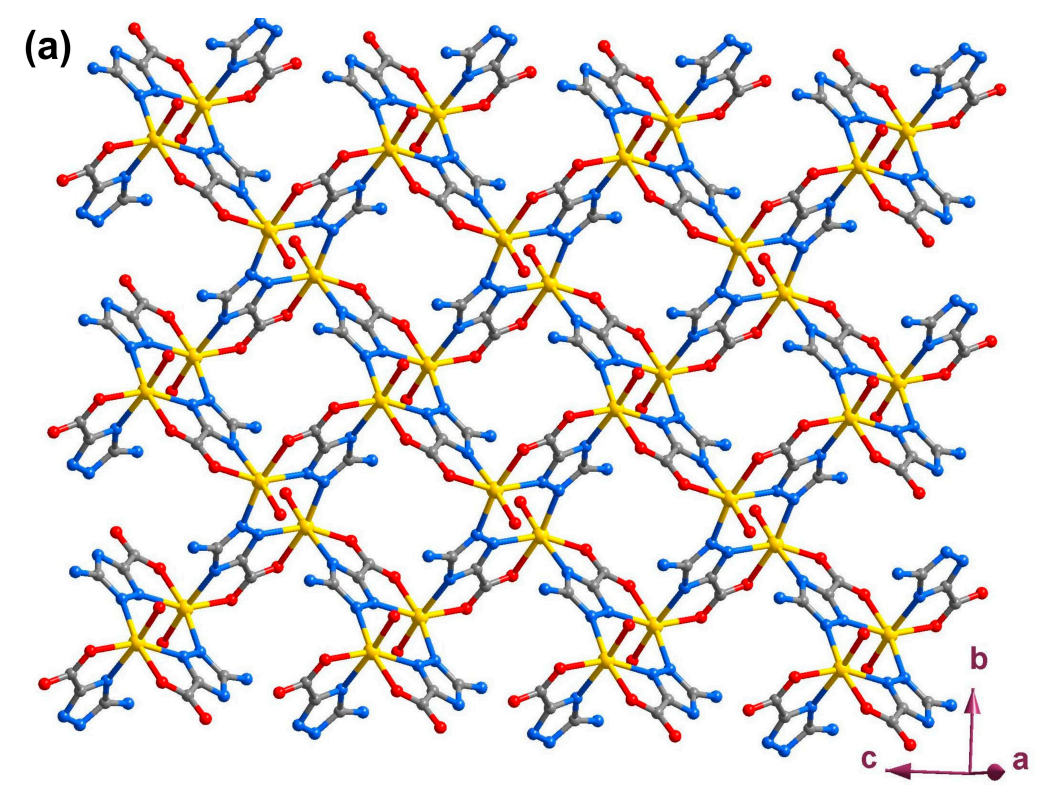

(b)
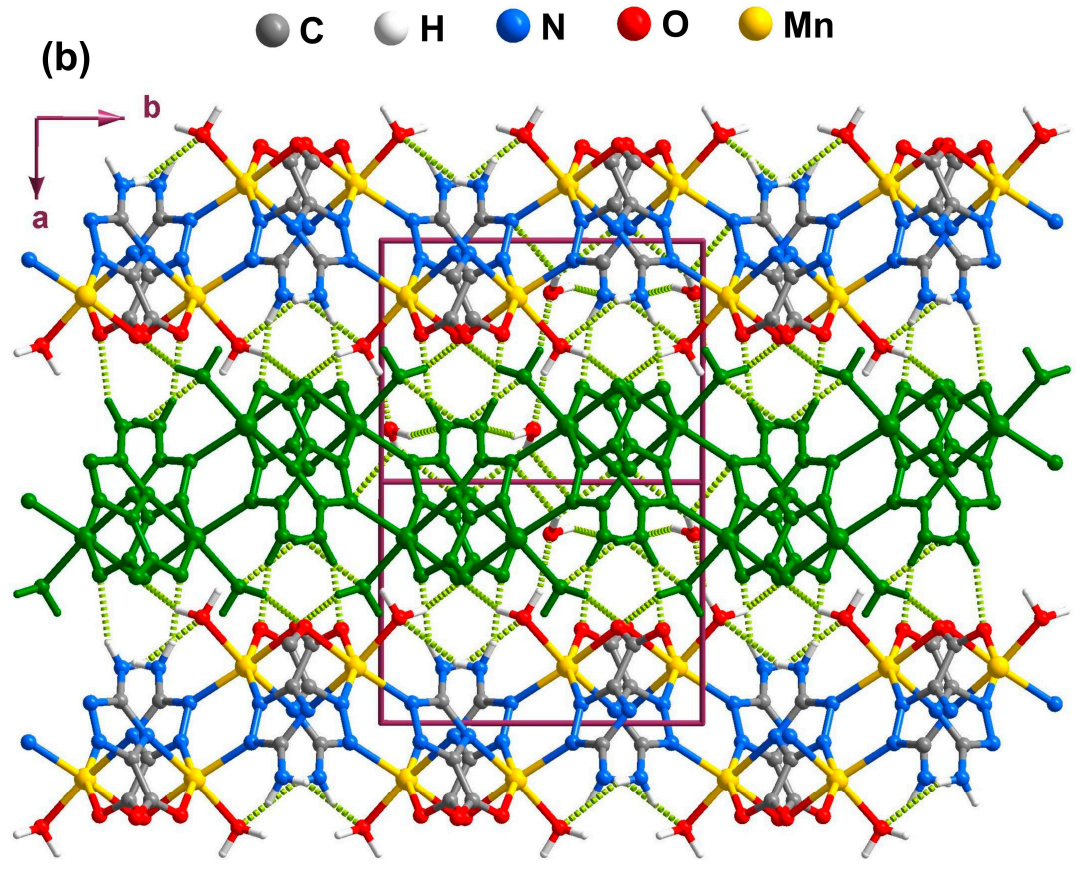

Figure 10. Ball-and-stick representation of (a) the 2D coordination layer and (b) 3D hydrogen-bonded network viewed along the [001] direction of the unit cell of compound 5 (layers represented with alternating colors). Hydrogen bonds are represented as dashed light-green lines. Geometric details on the represented supramolecular interactions are listed in Table 5.

\section{Experimental Section}

\subsection{Materials and Methods}

Most of the reagents and solvents were used directly as supplied commercially without further purification: 3-amino-1H-1,2,4-triazole-5-carboxylic acid (98\%, Sigma-Aldrich, St-Louis, MO, USA, 4,4'-bipyridine hydrate (Sigma-Aldrich, , 98\%), $\mathrm{ZnSO}_{4} \cdot 6 \mathrm{H}_{2} \mathrm{O}(99.5 \%+$, Merck, Kenilworth, NJ, USA), $\mathrm{MnCl}_{2} \cdot 4 \mathrm{H}_{2} \mathrm{O}$ (Sigma-Aldrich, $99.0 \%+$ ), $\mathrm{Mn}(\mathrm{OAc}) 2 \cdot 4 \mathrm{H}_{2} \mathrm{O}$ (Sigma-Aldrich, $99.0 \%+$ ), $\mathrm{CdBr}_{2} \cdot 4 \mathrm{H}_{2} \mathrm{O}(98.0 \%$, 
Sigma-Aldrich), $\mathrm{Fe}\left(\mathrm{NO}_{3}\right)_{3} \cdot 9 \mathrm{H}_{2} \mathrm{O}\left(99.0 \%+\right.$, Merck), $\mathrm{NaN}_{3}(99.0 \%+$, Sigma-Aldrich). Microcrystalline materials of $\mathrm{Mn}\left(\mathrm{ClO}_{4}\right)_{2} \cdot 6 \mathrm{H}_{2} \mathrm{O}$ and $\mathrm{Cd}\left(\mathrm{ClO}_{4}\right)_{2} \cdot 6 \mathrm{H}_{2} \mathrm{O}$ were isolated by freezing a reaction solution of $\mathrm{HClO}_{4}$ with excess of $\mathrm{MnCO}_{3}$ or $\mathrm{CdCO}_{3}$, respectively. (Caution: handling of perchlorate in solution or in the dry state should be performed in very small amounts and very carefully because these complexes are explosive in contact with organic or other readily oxidizable substances).

\subsection{Synthesis}

[Zn(Hatrc) $\left.2\left(\mathrm{H}_{2} \mathrm{O}\right)\right]$ (1). $\mathrm{H}_{2}$ atrc (4.992 mmol, $\left.0.6394 \mathrm{~g}\right)$ was dissolved in $500 \mathrm{~mL}$ of hot water, cooled to ambient temperature and then mixed with a $5 \mathrm{~mL} \mathrm{ZnSO} \cdot 7 \mathrm{H}_{2} \mathrm{O}(5.019 \mathrm{mmol}, 1.4404 \mathrm{~g})$ aqueous solution without stirring. Single crystals suitable for X-ray diffraction were obtained from the standing solution over a period of two weeks. FT-IR (KBr): $3435(v \mathrm{OH}), 3327(v \mathrm{~N}-\mathrm{H}(\cdots \mathrm{O})), 3220\left(v \mathrm{~N}-\mathrm{H}(\cdots \mathrm{O}), v \mathrm{NH}_{2}\right)$, $3121\left(v^{2} H_{2}\right), 2940(v N H, v C H), 27921656(v O-H(\cdots N)), 1599(v C=O), 1535(v C=N), 14771306(v C-O)$, $1120(\delta \mathrm{CH}, v \mathrm{rg}), 1063820(\gamma \mathrm{O}-\mathrm{H}(\cdots \mathrm{N})), 763727(\gamma \mathrm{O}-\mathrm{H}, \rho \mathrm{CH}), 642(\gamma \mathrm{rg}, v \mathrm{CN}), 491\left(\omega \mathrm{NH}_{2}\right), 399$ $(\delta \mathrm{C}-\mathrm{O}) \mathrm{cm}^{-1}$. FT-Raman: $3435(v \mathrm{~N}-\mathrm{H}(\cdots \mathrm{O})), 3285\left(v \mathrm{~N}-\mathrm{H}(\cdots \mathrm{O}), v \mathrm{NH}_{2}\right), 3220\left(\mathrm{vNH}_{2}\right), 3142,1656$ $(v \mathrm{C}=\mathrm{O}), 1535,1499,1456,1434(\delta \mathrm{NH}, v \mathrm{rg}), 1378(v \mathrm{C}-\mathrm{O}), 1299(\delta \mathrm{CH}, v \mathrm{rg}), 1106(\gamma \mathrm{CNH}, \gamma \mathrm{rg}, v \mathrm{CN}$ (ring)), $1070(v \mathrm{C}-\mathrm{O}, v \mathrm{C}-\mathrm{C}), 1042(\gamma \mathrm{O}-\mathrm{H}(\cdots \mathrm{N})), 813\left(\gamma \mathrm{O}-\mathrm{H}(\cdots \mathrm{N}), \gamma \mathrm{CNH}, \gamma \mathrm{NH}_{2}, \phi r g, \omega \mathrm{CN}\right), 756$ $(\gamma \mathrm{O}-\mathrm{H}, \rho \mathrm{CH}), 491(\delta \mathrm{C}-\mathrm{O}), 392\left(\tau \mathrm{NH}_{2}\right), 199\left(v \mathrm{M}-\mathrm{N}, \phi\left(\right.\right.$ out of plane) $\left.\mathrm{NH}_{2}, \gamma \mathrm{NCN}\right), 149,120 \mathrm{~cm}^{-1}$.

[Mn (Hatrc $\left.)_{2}\left(\mathrm{H}_{2} \mathrm{O}\right)_{2}\right] \cdot 2 \mathrm{H}_{2} \mathrm{O}$ (2). A similar procedure to that previously described for 1 was employed: $5 \mathrm{~mL}$ of a $\mathrm{MnCl}_{2} \cdot 4 \mathrm{H}_{2} \mathrm{O}(5.005 \mathrm{mmol}, 0.9904 \mathrm{~g})$ aqueous solution and $500 \mathrm{~mL}$ of a $\mathrm{H}_{2}$ atrc $(5.003 \mathrm{mmol}$, $0.6408 \mathrm{~g}$ ) aqueous solution promoted the formation of colorless block single crystals. FT-IR (KBr): 3306 $(v \mathrm{~N}-\mathrm{H}(\cdots \mathrm{O})), 3170(v \mathrm{NH} 2), 3020(v \mathrm{NH}, v \mathrm{CH}), 27841685(v \mathrm{O}-\mathrm{H}(\cdots \mathrm{N})), 1628(v \mathrm{C}=\mathrm{O}), 1556(v \mathrm{C}=\mathrm{N})$, $14991363(\delta \mathrm{NH}, v \mathrm{rg}), 1249(v \mathrm{C}-\mathrm{O}), 1113(\delta \mathrm{CH}, v \mathrm{rg}), 1049(v \mathrm{C}-\mathrm{O}, v \mathrm{C}-\mathrm{C}), 820(\gamma \mathrm{O}-\mathrm{H}(\cdots \mathrm{N})), 777699$ ( $\gamma \mathrm{rg}, \nu \mathrm{CN}), 627$ ( $\rho \mathrm{COO}), 463\left(\omega \mathrm{NH}_{2}\right), 399(\delta \mathrm{C}-\mathrm{O}) \mathrm{cm}^{-1}$. FT-Raman: 3177, $3020(v \mathrm{NH}, v \mathrm{CH}), 1685$ $(v \mathrm{C}=\mathrm{O}), 1553,1506(v \mathrm{vg}, \delta \mathrm{CH}, \delta \mathrm{NH}), 1420,1363(v \mathrm{C}-\mathrm{O}), 1242(\delta \mathrm{CH}, v \mathrm{rg}), 1113(\gamma \mathrm{CNH}, \gamma \mathrm{rg}, v \mathrm{CN}$ (ring)), $1049(\gamma \mathrm{O}-\mathrm{H}(\cdots \mathrm{N})), 799\left(\gamma \mathrm{O}-\mathrm{H}(\cdots \mathrm{N}), \gamma \mathrm{CNH}, \gamma \mathrm{NH}_{2}, \phi r g, \omega \mathrm{CN}\right), 727(\gamma \mathrm{rg}, \nu \mathrm{CN}), 570\left(\omega \mathrm{NH}_{2}\right)$, $463(\delta \mathrm{C}-\mathrm{O}), 399\left(\tau \mathrm{NH}_{2}\right), 227(\mathrm{vM}-\mathrm{N}), 192\left(v \mathrm{M}-\mathrm{N}, \phi\left(\right.\right.$ out of plane) $\left.\mathrm{NH}_{2}, \gamma \mathrm{NCN}\right), 127,99 \mathrm{~cm}^{-1}$.

[Fe( $\left.\mathrm{Hatrc})_{2}(\mathrm{OH})\right]_{2} \cdot 6 \mathrm{H}_{2} \mathrm{O}(\mathbf{3})$. An identical experimental procedure as that described for $\mathbf{1}$ was employed: $4.9985 \mathrm{mmol},(2.0194) \mathrm{g}$ of $\mathrm{Fe}\left(\mathrm{NO}_{3}\right)_{3} \cdot 9 \mathrm{H}_{2} \mathrm{O}(5 \mathrm{~mL})$ with $5.004 \mathrm{mmol}, 0.6410 \mathrm{~g}$ of $\mathrm{H}_{2} \operatorname{atrc}(500 \mathrm{~mL})$ produced orange block single crystals. FT-IR $(\mathrm{KBr}): 3392(\mathrm{vN}-\mathrm{H}(\cdots \mathrm{O})), 3258(\mathrm{vN}-\mathrm{H}(\cdots \mathrm{O}), v \mathrm{NH} 2)$, $3195\left(v \mathrm{NH}_{2}\right), 2941(v \mathrm{NH}, v \mathrm{CH}), 27721650(v \mathrm{O}-\mathrm{H}(\cdots \mathrm{N})), 1551(\mathrm{vC}=\mathrm{N}), 14591354(\delta \mathrm{NH}, v \mathrm{rg}), 1269$ $(v \mathrm{C}-\mathrm{O}), 1013(\delta \mathrm{CH}, v \mathrm{rg}), 909(v \mathrm{C}-\mathrm{O}, v \mathrm{C}-\mathrm{C}), 839(\gamma \mathrm{O}-\mathrm{H}(\cdots \mathrm{N})), 754726(\gamma \mathrm{O}-\mathrm{H}, \rho \mathrm{CH}), 655(\gamma \mathrm{rg}, v \mathrm{CN})$, $592(\rho \mathrm{COO}), 458(\omega \mathrm{NH} 2), 402(\delta \mathrm{C}-\mathrm{O}) \mathrm{cm}^{-1}$. FT-Raman: $3392\left(v \mathrm{~N}-\mathrm{H}(\cdots \mathrm{O}), v^{2} \mathrm{NH}_{2}\right), 3329\left(v \mathrm{NH}_{2}\right)$, 3181, $1643(v \mathrm{C}=\mathrm{O}), 1544,1466,1410(\delta \mathrm{NH}, v \mathrm{rg}), 1376(v \mathrm{C}-\mathrm{O}), 1114(\gamma \mathrm{CNH}, \gamma \mathrm{rg}, v \mathrm{CN}($ ring $)), 754$ $(\gamma \mathrm{O}-\mathrm{H}, \rho \mathrm{CH}), 564\left(\omega \mathrm{NH}_{2}\right), 500(\delta \mathrm{C}-\mathrm{O}), 402(\tau \mathrm{NH} 2), 303(v \mathrm{M}-\mathrm{N}), 162,112 \mathrm{~cm}^{-1}$.

$\left[C d(\operatorname{Hatrc})_{2}\left(\mathrm{H}_{2} \mathrm{O}\right)\right]_{n}(4) .5 \mathrm{~mL}$ of a mixture of $\mathrm{MeOH}$ and $\mathrm{H}_{2} \mathrm{O}(\mathrm{v}: \mathrm{v}=1: 1)$ was gently added dropwise onto $9 \mathrm{~mL}$ of an aqueous solution containing $\mathrm{H}_{2}$ atrc $(0.100 \mathrm{mmol}, 0.0128 \mathrm{~g})$ and $\mathrm{CdBr}_{2} \cdot 4 \mathrm{H}_{2} \mathrm{O}$ $(0.0999 \mathrm{mmol}, 0.0344 \mathrm{~g}) .8 \mathrm{~mL}$ of a $\mathrm{MeOH}$ solution of 4,4'-bipyridine $(0.0948 \mathrm{mmol}, 0.0148 \mathrm{~g})$ was added carefully as a third layer. Colorless block single crystals were obtained on the inner wall of the glass tube after a one week diffusion process. FT-IR $(\mathrm{KBr}): 3363(v \mathrm{~N}-\mathrm{H}(\cdots \mathrm{O})), 3235(v \mathrm{~N}-\mathrm{H}(\cdots \mathrm{O})$, 
$v \mathrm{NH} 2), 3142\left(v \mathrm{NH}_{2}\right), 2970(v \mathrm{NH}, v \mathrm{CH}), 27991670(v \mathrm{O}-\mathrm{H}(\cdots \mathrm{N})), 1620(v \mathrm{C}=\mathrm{O}), 1528(v \mathrm{C}=\mathrm{N}), 1477$ $1370(\delta \mathrm{NH}, v \mathrm{rg}), 1292(v \mathrm{C}-\mathrm{O}), 1128(\delta \mathrm{CH}, \operatorname{vrg}), 1070806(\gamma \mathrm{O}-\mathrm{H}(\cdots \mathrm{N})), 756713(\gamma \mathrm{O}-\mathrm{H}, \rho \mathrm{CH}), 663$ $(\gamma \mathrm{rg}, v \mathrm{CN}), 620(\rho \mathrm{COO}), 477\left(\omega \mathrm{NH}_{2}\right), 413(\delta \mathrm{C}-\mathrm{O}) \mathrm{cm}^{-1}$. FT-Raman: $3370\left(v \mathrm{~N}-\mathrm{H}(\cdots \mathrm{O}), v \mathrm{NH}_{2}\right), 3135$, $3070(v \mathrm{NH}, v \mathrm{CH}), 1606(v \mathrm{C}=\mathrm{N}), 1528,1485,1434(\delta \mathrm{NH}, v \mathrm{rg}), 1385(v \mathrm{C}-\mathrm{O}), 1292(\delta \mathrm{CH}, v \mathrm{rg}), 1235$, $1106(\gamma \mathrm{CNH}, \gamma \mathrm{rg}, v \mathrm{CN}($ ring $)), 1070(v \mathrm{C}-\mathrm{O}, v \mathrm{C}-\mathrm{C}), 1013(\gamma \mathrm{O}-\mathrm{H}(\cdots \mathrm{N})), 856(\gamma \mathrm{O}-\mathrm{H}(\cdots \mathrm{N}), \gamma \mathrm{CNH}$, $\left.\gamma \mathrm{NH}_{2}, \phi r g, \omega \mathrm{CN}\right), 763(\gamma \mathrm{O}-\mathrm{H}, \rho \mathrm{CH}), 656(\rho \mathrm{COO}),, 563\left(\omega \mathrm{NH}_{2}\right), 484(\delta \mathrm{C}-\mathrm{O}), 406(\tau \mathrm{NH} 2), 270,220$ $(v \mathrm{M}-\mathrm{N}), 199\left(v \mathrm{M}-\mathrm{N}, \phi(\right.$ out of plane $\left.) \mathrm{NH}_{2}, \gamma \mathrm{NCN}\right), 127 \mathrm{~cm}^{-1}$.

[Mn(atrc) $\left.\left(\mathrm{H}_{2} \mathrm{O}\right)\right]_{n} \cdot n \mathrm{H}_{2} \mathrm{O}$ (5). Method 1: $\mathrm{H}_{2}$ atrc $(0.602 \mathrm{mmol}, 0.0771 \mathrm{~g})$ was treated with $\mathrm{NaOH}$ $(0.6 \mathrm{mmol}, 0.0240 \mathrm{~g})$ in $15 \mathrm{~mL}$ of water with stirring at ambient temperature for $30 \mathrm{~min}$ to get a clear colorless solution. This solution was mixed with $\mathrm{Mn}\left(\mathrm{ClO}_{4}\right)_{2} \cdot 6 \mathrm{H}_{2} \mathrm{O}(0.199 \mathrm{mmol}, 0.0722 \mathrm{~g})$ in a $25 \mathrm{~mL}$ Teflon-lined stainless-steel reaction vessel. The mixture was heated at $100{ }^{\circ} \mathrm{C}$ for 5 days in a furnace and then cooled to obtain colorless crystals of $\mathbf{5}$. The same product can be obtained from the similar procedure using $\mathrm{MnCl}_{2} \cdot 4 \mathrm{H}_{2} \mathrm{O}$ or $\mathrm{Mn}(\mathrm{OAc})_{2} \cdot 4 \mathrm{H}_{2} \mathrm{O}$ instead of $\mathrm{Mn}\left(\mathrm{ClO}_{4}\right) \cdot 6 \mathrm{H}_{2} \mathrm{O}$.

Method 2: $\mathrm{H}_{2}$ atrc $(0.400 \mathrm{mmol}, 0.0512 \mathrm{~g})$ mixed with $\mathrm{NaN}_{3}(0.400 \mathrm{mmol}, 0.0260 \mathrm{~g})$ in $18 \mathrm{~mL}$ of water was stirred at ambient temperature for $30 \mathrm{~min}$ to get a clear colorless solution, which was mixed with $\mathrm{MnCl}_{2} \cdot 4 \mathrm{H}_{2} \mathrm{O}(0.205 \mathrm{mmol}, 0.0406 \mathrm{~g})$ in a $25 \mathrm{~mL}$ Teflon-lined stainless steel reaction vessel. The mixture was heated at $100{ }^{\circ} \mathrm{C}$ for 5 days in a furnace and then cooled slowly to ambient temperature to isolate a colorless crystalline material of compound 5. FT-IR $(\mathrm{KBr}): 3375(\mathrm{vN}-\mathrm{H}(\cdots \mathrm{O})), 3240$ $\left(v \mathrm{~N}-\mathrm{H}(\cdots \mathrm{O}), v \mathrm{NH}_{2}\right), 1620(v \mathrm{C}=\mathrm{O}), 1505(v \mathrm{C}=\mathrm{N}), 1318(v \mathrm{C}-\mathrm{O}), 1106(\delta \mathrm{CH}, v \operatorname{rg}), 849(\gamma \mathrm{O}-\mathrm{H}(\cdots \mathrm{N}))$, $746656(\gamma \mathrm{rg}, \nu \mathrm{CN}), 489(\omega \mathrm{NH} 2), 425(\delta \mathrm{C}-\mathrm{O}) \mathrm{cm}^{-1}$.

\subsection{Single Crystal X-ray Diffraction}

Single crystals of compounds 1-5 were manually harvested from the crystallization vials and mounted on Hampton Research CryoLoops using FOMBLIN Y perfluoropolyether vacuum oil (LVAC 25/6, purchased from Aldrich) [54] with the help of a Stemi 2000 stereomicroscope equipped with Carl Zeiss lenses. Data were collected with a Bruker X8 Kappa APEX II charge-coupled device (CCD) area-detector diffractometer (Mo-K $\alpha$ graphite-monochromated radiation, $\lambda=0.71073 \AA$ ) controlled by the APEX2 software package [55], and equipped with an Oxford Cryosystems Series 700 cryostream monitored remotely using Cryopad [56]. Images were processed using SAINT+ [57], and data were corrected for absorption by the multi-scan semi-empirical method implemented in SADABS [58]. The structures of compounds 1-5 were solved by direct methods using SHELXS [59] and refined using SHELXL [60] by full-matrix least-squares technique on $F^{2}$. All non-hydrogen atoms were refined anisotropically. Hydrogen atoms attached to $\mathrm{C}$ atoms were placed at geometrically calculated positions to their carrier atoms and refined with isotropic thermal parameters included in the final stage of the refinement, with $U_{\text {iso }}=1.2 \times U_{\text {eq }}$ of the atoms which they are attached. Hydrogen atoms associated with the water molecules and nitrogen atoms were located in difference Fourier maps. The $\mathrm{N}-\mathrm{H}, \mathrm{O}-\mathrm{H}$ and $\mathrm{H} \cdots \mathrm{H}$ distances were fixed using with $U_{\text {iso }}=1.5 \times U_{\text {eq }}$ of the atoms to which they are attached, plus appropriated DFIX distances $(\mathrm{N}-\mathrm{H} \quad 0.88 \AA, \mathrm{O}-\mathrm{H} \quad 0.95 \AA$ and $\mathrm{H} \cdots \mathrm{H} \quad 1.54 \AA)$. A summary of the structural determination and refinement details for compounds 1-5 is listed in Table 6. The highest peaks and deepest holes found in the structures refinement is listed in Table 7. CCDC 1403898-1403902 contain 
the supplementary crystallographic data for this paper. These data can be obtained free of charge from The Cambridge Crystallographic Data Centre via www.ccdc.cam.ac.uk/data_request/cif.

Table 6. Crystal and structure refinement data for compounds 1-5.

\begin{tabular}{|c|c|c|c|c|c|}
\hline & 1 & 2 & 3 & 4 & 5 \\
\hline Empirical formula & $\mathrm{C}_{6} \mathrm{H}_{8} \mathrm{~N}_{8} \mathrm{O}_{5} \mathrm{Zn}$ & $\mathrm{C}_{6} \mathrm{H}_{14} \mathrm{MnN}_{8} \mathrm{O}_{8}$ & $\mathrm{C}_{12} \mathrm{H}_{26} \mathrm{Fe}_{2} \mathrm{~N}_{16} \mathrm{O}_{16}$ & $\mathrm{C}_{6} \mathrm{H}_{8} \mathrm{CdN}_{8} \mathrm{O}_{5}$ & $\mathrm{C}_{3} \mathrm{H}_{6} \mathrm{MnN}_{4} \mathrm{O}_{4}$ \\
\hline Color and Habit & Colorless Plate & Colorless block & Orange block & Colorless block & Colorless block \\
\hline Crystal Size $\left(\mathrm{mm}^{3}\right)$ & $0.42 \times 0.21 \times 0.07$ & $0.08 \times 0.04 \times 0.03$ & $0.07 \times 0.02 \times 0.02$ & $0.07 \times 0.03 \times 0.04$ & $0.12 \times 0.11 \times 0.05$ \\
\hline Crystal system & Orthorhombic & Triclinic & Orthorhombic & Monoclinic & Monoclinic \\
\hline Space group & Pbcn & $P \overline{1}$ & Pnna & $P 2_{1} / n$ & $P 2_{1} / c$ \\
\hline$a(\AA)$ & $9.537(3)$ & $5.2482(9)$ & $27.111(6)$ & $8.9893(13)$ & $8.1472(6)$ \\
\hline$b \AA ́$ & $6.865(2)$ & $6.5330(11)$ & $12.697(3)$ & $8.9785(13)$ & $9.9846(7)$ \\
\hline$c(\AA ̊)$ & $17.120(5)$ & $10.6128(18)$ & $7.7352(17)$ & $13.9642(16)$ & $9.3679(6)$ \\
\hline$\alpha\left(^{\circ}\right)$ & 90 & $90.532(10)$ & 90 & 90 & 90 \\
\hline$\beta\left(^{\circ}\right)$ & 90 & $102.774(11)$ & 90 & $108.117(5)$ & 113.994(4) \\
\hline$\gamma\left(\left(^{\circ}\right)\right.$ & 90 & 109.139(10) & 90 & 90 & 90 \\
\hline$V\left(\AA^{3}\right)$ & $1120.8(6)$ & $333.93(10)$ & $2662.6(11)$ & $1071.2(3)$ & $696.20(8)$ \\
\hline$Z$ & 4 & 2 & 4 & 4 & 4 \\
\hline$D c\left(\mathrm{Mg} \mathrm{m}^{-3}\right)$ & 2.000 & 1.896 & 1.901 & 2.385 & 2.071 \\
\hline$\mu\left(\mathrm{mm}^{-1}\right)$ & 2.232 & 1.052 & 1.197 & 2.081 & 1.877 \\
\hline$F(000)$ & 680 & 195 & 1560 & 752 & 436 \\
\hline$\theta\left(^{\circ}\right)$ & 3.66 to 26.37 & 4.01 to 29.46 & 3.41 to 25.35 & 3.07 to 25.02 & 2.74 to 26.37 \\
\hline \multicolumn{6}{|l|}{ Data completeness } \\
\hline Reflections measured & 8019 & 5074 & 12255 & 13793 & 7382 \\
\hline Independent reflections & $1146\left(R_{\mathrm{int}}=0.0331\right)$ & $1055\left(R_{\mathrm{int}}=0.0411\right)$ & $2418\left(R_{\mathrm{int}}=0.0652\right)$ & $1878\left(R_{\mathrm{int}}=0.0512\right)$ & $1418\left(R_{\text {int }}=0.1497\right)$ \\
\hline Final $R_{1}, w R_{2}[I>2 \sigma(I)]$ & $0.0393,0.0867$ & $0.0514,0.0828$ & $0.0436,0.0807$ & $0.0432,0.1128$ & $0.0388,0.0896$ \\
\hline$R_{1}, w R_{2}($ all data $)$ & $0.0568,0.0944$ & $0.0603,0.0857$ & $0.087,0.0925$ & $0.0481,0.1150$ & $0.0474,0.0935$ \\
\hline$\Delta \rho_{\max / \min }\left(\mathrm{e} \AA^{-3}\right)$ & $0.389,-0.555$ & $0.384,-0.487$ & $0.364,-0.433$ & $0.729,-0.974$ & $0.555,-0.569$ \\
\hline
\end{tabular}

Table 7. Highest peaks and deepest holes for structure refinement data for compounds 1-5.

\begin{tabular}{|c|c|c|c|c|c|c|}
\hline & $\Delta \rho_{\max }\left(\mathrm{e} \AA^{-3}\right)$ & Distance/Á & from & $\Delta \rho_{\min }\left(\mathrm{e}^{-\AA^{-3}}\right)$ & Distance/Á & from \\
\hline 1 & 0.389 & 0.85 & $\mathrm{O} 1 \mathrm{~W}$ & -0.555 & 0.70 & $\mathrm{Zn} 1$ \\
\hline 2 & 0.384 & 1.17 & Mn1 & -0.487 & 0.61 & Mn1 \\
\hline 3 & 0.364 & 0.52 & $\mathrm{~N} 24$ & -0.433 & 0.64 & $\mathrm{Fe} 1$ \\
\hline 4 & 0.729 & 0.63 & $\mathrm{O} 3$ & -0.974 & 1.29 & H1A \\
\hline 5 & 0.555 & 0.90 & Mn1 & -0.569 & 0.96 & Mn1 \\
\hline
\end{tabular}

\section{Conclusions}

Employing 3-amino-1H-1,2,4-triazole-5-carboxylic acid as the organic ligand yielded the first series of five compounds, namely mononuclear [ $\left.\left.\mathrm{Zn}(\mathrm{Hatrc})_{2}\left(\mathrm{H}_{2} \mathrm{O}\right)\right](\mathbf{1}),\left[\mathrm{Mn}(\mathrm{Hatrc})_{2}\left(\mathrm{H}_{2} \mathrm{O}\right)_{2}\right] \cdot 2 \mathrm{H}_{2} \mathrm{O}(\mathbf{2})\right]$, binuclear $\left[\mathrm{Fe}_{2}(\mathrm{Hatrc})_{4}(\mathrm{OH})_{2}\right] \cdot 6 \mathrm{H}_{2} \mathrm{O}$ (3), $1 \mathrm{D}$ zigzag chain $\left[\mathrm{Cd}(\mathrm{Hatrc})_{2}\left(\mathrm{H}_{2} \mathrm{O}\right)\right]_{n}$ (4), and 2D layer $\left[\mathrm{Mn}(\operatorname{atrc})\left(\mathrm{H}_{2} \mathrm{O}\right)\right]_{n} \cdot n \mathrm{H}_{2} \mathrm{O}(\mathbf{5})$. All compounds were isolated as single crystals. 
In this series, $(\mathrm{H})$ atrc ligands adopt three types of connection fashions: in $\mathbf{1}-\mathbf{3}$, they chelate preferentially with the metal centers via the carboxylic $\mathrm{O}$ atom and the 4-position $\mathrm{N}$ atom to form a five-membered ring; in 4, with one more metal center chelated by two carboxylic $\mathrm{O}$ atoms, the discrete units can shape a polymeric 1D chain; in $\mathbf{5}$, based on the fashion in $\mathbf{4}$, two more metal centers are bound through, on the one hand, a similar five-membered ring being formed by the 2-positioned $\mathrm{N}$ atom and the second carboxylic $\mathrm{O}$ atom and, on the other, the fourth metal being connected to the 1-positioned $\mathrm{N}$ atom. The various coordination fashions play, in this respect, a significant role in the structural fabrication of the various compounds. The residual uncoordinated donor sites in the anionic ligands in compounds $\mathbf{1}-\mathbf{4}$ open the possibility to use compounds $\mathbf{1}-\mathbf{4}$ as precursors of building blocks to further isolate multidimensional frameworks. With the rich existence of donors and acceptors in the present structures, the hydrogen-bonding interactions with the various water molecules incorporated into the materials play key roles in the supramolecular organization leading to the formation of 3D supramolecular architectures.

\section{Supplementary Materials}

Supplementary materials can be accessed at: http://www.mdpi.com/1420-3049/20/07/12341/s1.

\section{Acknowledgments}

Fundação para a Ciência e a Tecnologia (FCT, Portugal), the European Union, QREN, FEDER through Programa Operacional Factores de Competitividade (COMPETE), CICECO-Aveiro Institute of Materials (Ref. FCT UID/CTM/50011/2013) and REQUIMTE/LAQV (Ref. FCT UID/QUI/50006/2013) financed by national funds through the FCT/MEC and when applicable co-financed by FEDER under the PT2020 Partnership Agreement.

We wish to thank FCT for funding the R \& D projects FCOMP-01-0124-FEDER-041282 (Ref. FCT EXPL/CTM-NAN/0013/2013) and FCOMP-01-0124-FEDER-041445 (Ref. FCT EXPL/ QEQ-QUI/0199/2013) and CICECO for specific funding towards the purchase of the single-crystal diffractometer. FCT is also gratefully acknowledged for the Post-Doctoral research grants Nos. SFRH/BPD/63736/2009 and SFRH/BPD/47566/2008 (to J.A.F. and B.L., respectively).

\section{Author Contributions}

B.L. and L.C.-S. designed and carried out the synthesis and preliminary characterization of the compounds. J.A.F. and F.A.A.P. carried out the crystallographic studies. J.P.C.T. was responsible for the analysis and discussion of the characterization of the organic linker supervising B.L in this task. All authors actively contributed to the writing up of the manuscript.

\section{Conflicts of Interest}

The authors declare no conflicts of interest.

\section{References}

1. Eddaoudi, M.; Li, H.L.; Yaghi, O.M. Highly porous and stable metal-organic frameworks: Structure design and sorption properties. J. Am. Chem. Soc. 2000, 122, 1391-1397. 
2. James, S.L. Metal-organic frameworks. Chem. Soc. Rev. 2003, 32, 276-288.

3. Kaczorowski, T.; Justyniak, I.; Lipinska, T.; Lipkowski, J.; Lewinski, J. Metal Complexes of Cinchonine as Chiral Building Blocks: A Strategy for the Construction of Nanotubular Architectures and Helical Coordination Polymers. J. Am. Chem. Soc. 2009, 131, 5393-5395.

4. Maspoch, D.; Ruiz-Molina, D.; Veciana, J. Old materials with new tricks: Multifunctional open-framework materials. Chem. Soc. Rev. 2007, 36, 770-818.

5. Nayak, S.; Harms, K.; Dehnen, S. New Three-Dimensional Metal-Organic Framework with Heterometallic Fe-Ag Building Units: Synthesis, Crystal Structure, and Functional Studies. Inorg. Chem. 2011, 50, 2714-2716.

6. Robin, A.Y.; Fromm, K.M. Coordination polymer networks with O- and N-donors: What they are, why and how they are made. Coord. Chem. Rev. 2006, 250, 2127-2157.

7. Zhao, Y.G.; Wu, H.H.; Emge, T.J.; Gong, Q.H.; Nijem, N.; Chabal, Y.J.; Kong, L.Z.; Langreth, D.C.; Liu, H.; Zeng, H.P.; et al. Enhancing Gas Adsorption and Separation Capacity through Ligand Functionalization of Microporous Metal-Organic Framework Structures. Chem. Eur. J. 2011, 17, 5100-5108.

8. Chen, S.M.; Zhang, J.; Wu, T.; Feng, P.Y.; Bu, X.H. Multiroute Synthesis of Porous Anionic Frameworks and Size-Tunable Extraframework Organic Cation-Controlled Gas Sorption Properties. J. Am. Chem. Soc. 2009, 131, 16027-16029.

9. Matsuda, R.; Kitaura, R.; Kitagawa, S.; Kubota, Y.; Belosludov, R.V.; Kobayashi, T.C.; Sakamoto, H.; Chiba, T.; Takata, M.; Kawazoe, Y.; et al. Highly controlled acetylene accommodation in a metal-organic microporous material. Nature 2005, 436, 238-241.

10. Moulton, B.; Zaworotko, M.J. From molecules to crystal engineering: Supramolecular isomerism and polymorphism in network solids. Chem. Rev. 2001, 101, 1629-1658.

11. Noro, S.; Kitaura, R.; Kondo, M.; Kitagawa, S.; Ishii, T.; Matsuzaka, H.; Yamashita, M. Framework engineering by anions and porous functionalities of $\mathrm{Cu}(\mathrm{II}) / 4,4^{\prime}$-bpy coordination polymers. J. Am. Chem. Soc. 2002, 124, 2568-2583.

12. Su, C.Y.; Cai, Y.P.; Chen, C.L.; Smith, M.D.; Kaim, W.; zur Loye, H.C. Ligand-directed molecular architectures: Self-assembly of two-dimensional rectangular metallacycles and three-dimensional trigonal or tetragonal prisms. J. Am. Chem. Soc. 2003, 125, 8595-8613.

13. Fujita, M.; Tominaga, M.; Hori, A.; Therrien, B. Coordination assemblies from a Pd(II)-cornered square complex. Acc. Chem. Res. 2005, 38, 369-378.

14. Leininger, S.; Olenyuk, B.; Stang, P.J. Self-assembly of discrete cyclic nanostructures mediated by transition metals. Chem. Rev. 2000, 100, 853-907.

15. Carlucci, L.; Ciani, G.; Proserpio, D.M. Polycatenation, polythreading and polyknotting in coordination network chemistry. Coord. Chem. Rev. 2003, 246, 247-289.

16. Pitt, M.A.; Johnson, D.W. Main group supramolecular chemistry. Chem. Soc. Rev. 2007, 36, 1441-1453.

17. Andraud, C.; Maury, O. Lanthanide Complexes for Nonlinear Optics: From Fundamental Aspects to Applications. Eur. J. Inorg. Chem. 2009, 2009, 4357-4371.

18. Bauer, C.A.; Timofeeva, T.V.; Settersten, T.B.; Patterson, B.D.; Liu, V.H.; Simmons, B.A.; Allendorf, M.D. Influence of connectivity and porosity on ligand-based luminescence in zinc metal-organic frameworks. J. Am. Chem. Soc. 2007, 129, 7136-7144. 
19. Deplano, P.; Pilia, L.; Espa, D.; Mercuri, M.L.; Serpe, A. Square-planar $\mathrm{d}^{8}$ metal mixed-ligand dithiolene complexes as second order nonlinear optical chromophores: Structure/property relationship. Coord. Chem. Rev. 2010, 254, 1434-1447.

20. Kuang, G.C.; Ji, Y.; Jia, X.R.; Chen, E.Q.; Gao, M.; Yeh, J.M.; Wei, Y. Supramolecular Self-Assembly of Dimeric Dendrons with Different Aliphatic Spacers. Chem. Mater. 2009, 21, 456-462.

21. Zhang, J.J.; Wojtas, L.; Larsen, R.W.; Eddaoudi, M.; Zaworotko, M.J. Temperature and Concentration Control over Interpenetration in a Metal-Organic Material. J. Am. Chem. Soc. 2009, 131, 17040-17041.

22. Aromi, G.; Barrios, L.A.; Roubeau, O.; Gamez, P. Triazoles and tetrazoles: Prime ligands to generate remarkable coordination materials. Coord. Chem. Rev. 2011, 255, 485-546.

23. Dias, H.V.R.; Singh, S.; Campana, C.F. Toluene-sandwiched trinuclear copper(I) and silver(I) triazolates and phosphine adducts of dinuclear copper(I) and silver(I) triazolates. Inorg. Chem. 2008, 47, 3943-3945.

24. Fillat, M.F.; Gimeno, M.C.; Laguna, A.; Latorre, E.; Ortego, L.; Villacampa, M.D. Synthesis, Structure and Bactericide Activity of (Aminophosphane)gold(I) Thiolate Complexes. Eur. J. Inorg. Chem. 2011, 1487-1495.

25. Kitchen, J.A.; Brooker, S. Spin crossover in iron(II) complexes of 3,5-di(2-pyridyl)-1,2,4-triazoles and 3,5-di(2-pyridyl)-1,2,4-triazolates. Coord. Chem. Rev. 2008, 252, 2072-2092.

26. Kitchen, J.A.; White, N.G.; Jameson, G.N.L.; Tallon, J.L.; Brooker, S. Effect of Counteranion X on the Spin Crossover Properties of a Family of Diiron(II) Triazole Complexes $\mathrm{Fe}_{2}{ }^{\mathrm{II}}(\mathrm{PMAT})_{2} \mathrm{X}_{4}$. Inorg. Chem. 2011, 50, 4586-4597.

27. Li, B.Y.; Jin, D.; Ma, B.H.; Liu, D.; Li, G.H.; Shi, Z.; Feng, S.H. Two Coordination Polymers with Rare Topologies Based on Copper(II) and Ligands Generated by in Situ Reactions. Eur. J. Inorg. Chem. 2011, 2011, 35-38.

28. Riederer, S.K.U.; Bechlars, B.; Herrmann, W.A.; Kühn, F.E. Synthesis and Structural Characterization of New Chiral (Biscarbene)platinum(II) Complexes. Eur. J. Inorg. Chem. 2011, 2011, 249-254.

29. Tekarli, S.M.; Cundari, T.R.; Omary, M.A. Rational design of macrometallocyclic trinuclear complexes with superior $\pi$-acidity and $\pi$-basicity. J. Am. Chem. Soc. 2008, 130, 1669-1675.

30. Wei, W.T.; Lu, Y.Z.; Chen, W.; Chen, S.W. One-Pot Synthesis, Photoluminescence, and Electrocatalytic Properties of Subnanometer-Sized Copper Clusters. J. Am. Chem. Soc. 2011, 133, 2060-2063.

31. Yamada, T.; Maruta, G.; Takeda, S. Reversible solid-state structural conversion between a three-dimensional network and a one-dimensional chain of $\mathrm{Cu}(\mathrm{II})$ triazole coordination polymers in acidic/basic-suspensions or vapors. Chem. Commun. 2011, 47, 653-655.

32. Fernandes, J.A.; Liu, B.; Tomé, J.P.C.; Cunha-Silva, L.; Paz, F.A.A. 5-Amino-1H-1,2,4-triazol-4ium-3-carboxylate hemihydrate. Acta Cryst. E 2011, 67, O2073-U2868.

33. Allen, F.H. The Cambridge Structural Database: A quarter of a million crystal structures and rising. Acta Cryst. B 2002, 58, 380-388.

34. Wang, J.; Li, W.Z.; Wang, J.G.; Xiao, H.P. Crystal structure of diaquabis(3-amino-1,2,4-triazole5-carboxylato)-cadmium(II), $\mathrm{Cd}\left(\mathrm{H}_{2} \mathrm{O}\right)_{2}\left(\mathrm{C}_{3} \mathrm{H}_{3} \mathrm{~N}_{4} \mathrm{O}_{2}\right)_{2}$. Z. Krist. New Cryst. Struct. 2011, 226, $163-164$.

35. Siddiqui, K.A.; Mehrotra, G.K.; Narvi, S.S.; Butcher, R.J. Molecular self-assembly of cadmium-triazolate complexes via hydrogen bonding: Synthesis, structures and photoluminescent properties. Inorg. Chem. Commun. 2011, 14, 814-817. 
36. Chen, Y.C.; Xu, J.J.; Wang, K.B.; Wang, Y. Syntheses and characterization of two new alkaline earth metal-organic topological frameworks with 3-amino-1H-1,2,4-triazole-5-carboxylate. Chin. J. Struct. Chem. 2011, 30, 799-804.

37. Tseng, T.W.; Luo, T.T.; Lu, K.H. Impeller-like dodecameric water clusters in metal-organic nanotubes. CrystEngComm 2014, 16, 5516-5519.

38. Shi, F.N.; Cunha-Silva, L.; Hardie, M.J.; Trindade, T.; Paz, F.A.A.; Rocha, J. Heterodimetallic germanium(IV) complex structures with transition metals. Inorg. Chem. 2007, 46, 6502-6515.

39. Shi, F.N.; Cunha-Silva, L.; Paz, F.A.A.; Hardie, M.J.; Klinowski, J.; Rocha, J.; Trindade, T. A novel germanium(IV) oxalate complex: $\mathrm{Ge}(\mathrm{OH})_{2}\left(\mathrm{C}_{2} \mathrm{O}_{4}\right)_{2}{ }^{2-}$. Inorg. Chem. Commun. 2008, 11, 283-287.

40. Cunha-Silva, L.; Shi, F.N.; Paz, F.A.A.; Hardie, M.J.; Klinowski, J.; Trindade, T.; Rocha, J. Supramolecular salts containing the anionic $\mathrm{Ge}\left(\mathrm{C}_{2} \mathrm{O}_{4}\right)_{3}{ }^{2-}$ complex and heteroaromatic amines. Inorg. Chim. Acta 2009, 362, 263-270.

41. Neves, P.; Gago, S.; Balula, S.S.; Lopes, A.D.; Valente, A.A.; Cunha-Silva, L.; Almeida Paz, F.A.; Pillinger, M.; Rocha, J.; Silva, C.M.; et al. Synthesis and Catalytic Properties of Molybdenum(VI) Complexes with Tris(3,5-dimethyl-1-pyrazolyl)methane. Inorg. Chem. 2011, 50, 3490-3500.

42. Ananias, D.; Kostova, M.; Paz, F.A.A.; Ferreira, A.; Carlos, L.D.; Klinowski, J.; Rocha, J. Photoluminescent layered lanthanide silicates. J. Am. Chem. Soc. 2004, 126, 10410-10417.

43. Klinowski, J.; Paz, F.A.A.; Silva, P.; Rocha, J. Microwave-Assisted Synthesis of Metal-Organic Frameworks. Dalton Trans. 2011, 40, 321-330.

44. Rocha, J.; Carlos, L.D.; Paz, F.A.A.; Ananias, D. Luminescent multifunctional lanthanides-based metal-organic frameworks. Chem. Soc. Rev. 2011, 40, 926-940.

45. Rocha, J.; Paz, F.A.A.; Shi, F.N.; Ananias, D.; Silva, N.J.O.; Carlos, L.D.; Trindade, T. Mixed-Metal d-f Phosphonate Frameworks-Photoluminescence and Magnetic Properties. Eur. J. Inorg. Chem. 2011, 2011, 2035-2044.

46. Shi, F.N.; Cunha-Silva, L.; Ferreira, R.A.S.; Mafra, L.; Trindade, T.; Carlos, L.D.; Paz, F.A.A.; Rocha, J. Interconvertable modular framework and layered lanthanide(III)-etidronic acid coordination polymers. J. Am. Chem. Soc. 2008, 130, 150-167.

47. Soares-Santos, P.C.R.; Cunha-Silva, L.; Sousa, F.L.; Sousa, J.L.C.; Gates, P.J.; Klinowski, J.; Trindade, T.; Rocha, J.; Cavaleiro, A.M.V.; Paz, F.A.A.; et al. A new supramolecular organic-inorganic adduct: $\left\{\left[\mathrm{Eu}\left(\mathrm{CH}_{3} \mathrm{OH}\right)\left(\mathrm{H}_{2} \mathrm{O}\right)_{8}\right]_{2}\left[\mathrm{Eu}\left(\mathrm{H}_{2} \mathrm{O}\right)_{8}\right]\left[\mathrm{PW}_{12} \mathrm{O}_{40}\right]_{3}\right\} \bullet 8\left(\mathrm{C}_{14} \mathrm{H}_{20} \mathrm{O}_{5}\right) \cdot 2\left(\mathrm{C}_{28} \mathrm{H}_{40} \mathrm{O}_{10}\right) \bullet 6\left(\mathrm{CH}_{3} \mathrm{OH}\right) \bullet 6\left(\mathrm{H}_{2} \mathrm{O}\right)$. J. Mol. Struct. 2011, 989, 80-85.

48. Addison, A.W.; Rao, T.N.; Reedijk, J.; Vanrijn, J.; Verschoor, G.C. Synthesis, structure, and spectroscopic properties of copper(II) compounds containing nitrogen sulfur donor ligands-The crystal and molecular-structure of aqua 1,7-bis( $N$-methylbenzimidazol-2'-yl)-2,6-dithiaheptane copper(II) perchlorate. Dalton Trans. 1984, 7, 1349-1356.

49. Spek, A. Structure validation in chemical crystallography. Acta Cryst. D 2009, 65, 148-155.

50. Grell, J.; Bernstein, J.; Tinhofer, G. Graph-set analysis of hydrogen-bond patterns: Some mathematical concept. Acta Cryst. B 1999, 55, 1030-1043.

51. Ding, B.; Yi, L.; Wang, Y.; Cheng, P.; Liao, D.Z.; Yan, S.P.; Jiang, Z.H.; Song, H.B.; Wang, H.G. Synthesis of a series of 4-pyridyl-1,2,4-triazole-containing cadmium(II) luminescent complexes. Dalton Trans. 2006, 665-675, doi:10.1039/B508332J. 
52. Habib, H.A.; Hoffmann, A.; Hoeppe, H.A.; Janiak, C. Crystal structures and solid-state CPMAS ${ }^{13} \mathrm{C}$ NMR correlations in luminescent zinc(II) and cadmium(II) mixed-ligand coordination polymers constructed from 1,2-bis(1,2,4-triazol-4-yl)ethane and benzenedicarboxylate. Dalton Trans. 2009, 1742-1751, doi:10.1039/b812670d.

53. Li, B.L.; Zhu, X.; Zhou, J.H.; Peng, Y.F.; Zhang, Y. Syntheses and structures of five cadmium(II) coordination polymers from 1,2-bis(1,2,4-triazol-1-yl)ethane. Polyhedron 2004, 23, 3133-3141.

54. Kottke, T.; Stalke, D. Crystal handling at low temperatures. J. Appl. Crystallogr. 1993, 26, 615-619.

55. APEX2. Data Collection Software Version 2.1-RC13; Bruker AXS: Delft, The Netherlands, 2006.

56. Cryopad. Remote Monitoring and Control, Version 1.451; Oxford Cryosystems: Oxford, UK, 2006.

57. SAINT+. Data Integration Engine, version 7.23a; Bruker AXS: Madison, WI, USA, 1997-2005.

58. Sheldrick, G.M. SADABS v.2.01, Bruker/Siemens Area Detector Absorption Correction Program 1998; Bruker AXS: Madison, WI, USA.

59. Sheldrick, G.M. SHELXS-97, Program for Crystal Structure Solution; University of Göttingen: Göttingen, Germany, 1997.

60. Sheldrick, G.M. SHELXL-97, Program for Crystal Structure Refinement; University of Göttingen: Göttingen, Germany, 1997.

Sample Availability: Samples of the compounds are not available from the authors.

(C) 2015 by the authors; licensee MDPI, Basel, Switzerland. This article is an open access article distributed under the terms and conditions of the Creative Commons Attribution license (http://creativecommons.org/licenses/by/4.0/). 